\title{
Hospital Waste Shredder Test Series at the DONLEE Pilot Test Facility
}

Final Report

Work Performed Under Contract No.: DE-FG21-88MC25033

For

U.S. Department of Energy

Office of Fossil Energy

Morgantown Energy Technology Center

P.O. Box 880

Morgantown, West Virginia 26507-0880

Good Samaritan Hospital

4th and Walnut Streets

Lebanon, Pennsylvania 17042

and

York-Shipley Energy Systems

A Division of DONLEE Technologies Inc.

693 North Hills Road

York, Pennsylvania 17402

September 1992 


\section{PREFACE}

This report describes the coal firing and coal and noninfectious hospital waste co-firing testing and emissions rates for the tests conducted at the DONLEE pilot plant facility during mid-December 1991 through early March 1992. The emissions obtained during these tests are in turn used to predict the emission rates for the proof-of-concept facility that is to be built at the Lebanon Veterans Affairs Medical Center. In addition, the reliability and performance of the waste shredding/feeding system were evaluated from this testing. 


\section{ACKNOWLEDGEMENTS}

This report was prepared by DONLEE Technologies Inc. for the Good Samaritan Hospital under the direction of Mr. Robert Hoffman and Mr. James Sak. Technical guidance was provided by Morgantown Energy Technology Center with Mr. Arthur Hall and Mr. Gary Nelkin acting as project officers. The project was administered for DOE by Ms. Brenda Summers and Ms. Laura Brandt. Financial support was also provided by the Pennsylvania Energy Development Authority (PEDA) with Mr. Tony Rametta acting as PEDA's project officer. 


\section{EXECUTIVE SUMMARY}

Testing was conducted at DONLEE Technologies Inc.'s fluidized bed pilot plant from midDecember 1991 through early March of 1992. The combustion system and, in particular, the shredding/feeding system were tested and evaluated for their operation and performance. Coal and limestone were co-fired with noninfectious waste obtained from the Lebanon Veterans Affairs (VA) Medical Center which is where the proof-of-concept steam generation/combustion system will be installed.

The objectives of the testing were as follows:

- to test the waste shredding/feeding system and to demonstrate the performance and reliability of the system;

- to determine the emissions generated from coal-firing and from coal and waste co-firing; and

- to predict emissions for the Lebanon VA Medical Center proof-of-concept unit from the pilot plant emissions test data.

The performance and reliability of the shredding/feeding system were demonstrated during testing. The emissions, including $\mathrm{SO}_{2}, \mathrm{NO}_{\mathrm{x}}, \mathrm{HCl}$, dioxins/furans and trace (or heavy) metals all met the Federal and Pennsylvania air quality regulations or guidelines. The particulates and $\mathrm{CO}$ emissions from the hituminous coal tests did not meet these guidelines. However, note that during the anthracite tests all of the gaseous emissions, including the $\mathrm{CO}$, met all Federal regulations and Pennsylvania guidelines. Anthracite coal has been selected as the fuel at the Lebanon VA facility. High particulate emissions from the pilot plant, when firing either bituminous coal or anthracite, resulted from overloading the baghouse (Note that the baghouse is undersized for this facility and the fact that the bags were several years old). The predicted emissions for the Lebanon VA facility will meet, or even be much lower than, the pilot plant test results and thus will meet all of the required regulations and guidelines. 


\section{TABLE OF CONTENTS}

Page

PREFACE.................................................. i

ACKNOWLEDGEMENT ......................................... ii

EXECUTIVE SUMMARY........................................... iii

TABLE OF CONTENTS $\ldots \ldots \ldots \ldots \ldots \ldots \ldots \ldots \ldots \ldots \ldots \ldots \ldots \ldots \ldots, v$

LIST OF FIGURES............................................ vi

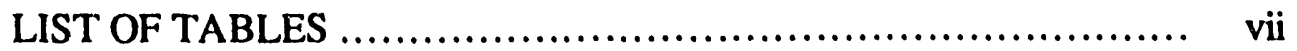

LIST OF ACRONYMS AND ABBREVIATIONS....................... viii

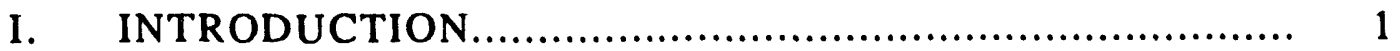

II. PURPOSE................................................... 3

III. EQUIPMENT DESCRIPTION............................... 4

IV. RELIABILITY TEST DESCRIPTION ........................... 7

A. COAL AND LIMESTONE FEEDSTOCKS ................. 7

V. RELIABILITY TEST RESULTS $\ldots \ldots \ldots \ldots \ldots \ldots \ldots \ldots \ldots \ldots \ldots \ldots, 10$

VI. SHREDDER TEST DESCRIPTION................................ 11

VII. SHREDDER TEST RESULTS .................................. 13

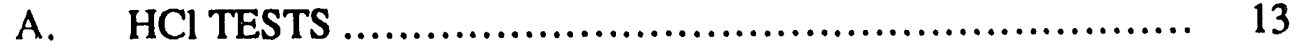

B. DIOXIN/FURAN AND PAH TESTS ...................... 13

C. TRACE OR HEAVY METAL AND PARTICULATES TESTS . 14

D. $\mathrm{SO}_{2}, \mathrm{NO}_{\mathrm{x}}$ AND CO EMISSIONS ...................... 17

VIII. ANTHRACITE COAL TEST DESCRIPTION..................... 19

IX. AN'TIRACITE COAL TESI RESUL'TS ........................ 20

A. ANTHRACITE SULFUR CAPTURE TESTS ................ 20

B. ANTHRACITE $\mathrm{NO}_{\mathrm{x}}$ AND CO EMISSION RATES ........... 22

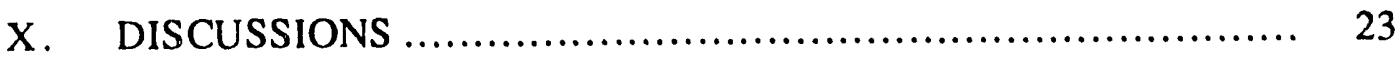

A. RELIABILITY TESTS ................................ 23

B. SHREDDER TESTS ................................... 23

C. ANTHRACITE COAL TESTS ........................... 23 
XI. PREDICTIONS ............................................... 24

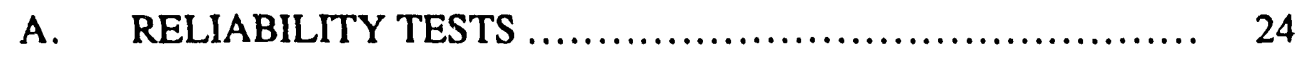

B. SHREDDER TESTS .................................... 24

1. $\mathrm{HCl}$ Tests .......................................... 24

2. Dioxin/Furan and PAH Tests............................... 25

3. Trace or Heavy Metals and Particulates Tests ............. 26

4. $\mathrm{SO}_{2}$ Emissions ..................................... 27

5. NO Emissions............................................... 27

6. CO Emissions ...................................... 27

C. EMISSION COMPLIANCE .............................. 28

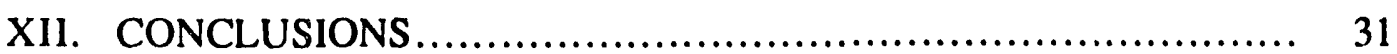

XIII. REFERENCES ............................................ 32

APPENDIX: ENVIRONMENTAL CONSULTANT COMPANY

REPORT ON P-84 BAG MATERIAL

\section{LIST OF FIGURES}

Figure 1. Circulating Fluidized Bed Combustor............................. 4

Figure 2. Waste Feed System......................................... 5

Figure 3. Sulfur Capture During Shredder Tests...................... 18

Figure 4. Sulfur Capture During Anthracite Tests......................... 21 


\section{LIST OF TABLES}

Page

Table 1a. Coal Size Distributions.................................... 7

Table 1b. Limestone Size Distribution ................................ 8

Table 2a. Coal Chemical Compositions ............................... 8

Table 2b. Limestone Compositions ................................. 9

Table 3. Trace or Heavy Metal (and Fluorine) Analyses ................ 9

Table 4. Test Conditions for Hospital Waste

Shredder/Feeder Test Series.................................... 11

Table 5. Test Conditions for Anthracite Coal Test Series ................. 14

Table 6. Metal Emissions - Pilot Plant Tests and

Predicted Lebanon VA Facility Values........................ 14

Table 7. Baghouse Capture Efficiencies.................................. 15

Table 8. Trace Metals from Hospital Waste............................... 16

Table 9. Sulfur Dioxide and Nitrogen Oxides Emissions ............... 17

Table 10. Test Conditions for Anthracite Coal Test Series ................ 19

Table 11. Sulfur Capture ......................................... 20

Table 12. Anthracite Emissions Rates..................................... 22

Table 13. Stack Metal and Particulate Emissions
Predicted Lebanon VA Facility Values....................... 26

Table 14. Average CO Emission Concentration ....................... 28

Table 15. Emission Levels Summary Versus Regulations ................... 29 


\section{LIST OF ACRONYMS AND ABBREVIATIONS}

$\begin{array}{ll}\text { BAT } & \text { Best Available Technology } \\ \text { CFB } & \text { Circulating Fluidized Bed } \\ \text { DOE } & \text { U.S. Department of Energy } \\ \text { EPA } & \text { U.S. Environmental Protection Agency } \\ \text { NSPS } & \text { New Source Performance Standards } \\ \text { PA DER } & \text { Pennsylvania Department of Environmental Protection } \\ \text { PAH } & \text { Polyaromatic Hydrocarbons } \\ \text { PEDA } & \text { Pennsylvania Energy Development Authority } \\ \text { PF } & \text { Prediction Factor } \\ \text { VA } & \text { Veterans Affairs }\end{array}$




\section{HOSPITAL WASTE SHREDDER TEST SERIES AT THE DONLEE PILOT TEST FACILITY}

\section{INTRODUCTION}

The Morgantown Energy Technology Center (U. S. Department of Energy), the Pennsylvania Energy Development Authority, and DONLEE Technologies Inc. are involved in a project to demonstrate environmentally safe destruction of infectious hospital waste by co-firing the waste with coal in a circulating fluidized bed (CFB) combustion system. The technology will provide steam generation as well as waste destruction at the full-scale proof-of-concept CFB facility to be located at the Veterans Affairs (VA) Medical Center in Lebanon, Pennsylvania. Coal fired CFB combustion systems have already proven that they can achieve gaseous and particulate emissions lower than the latest New Source Performance Standards (NSPS). Co-firing the hospital waste with coal in a CFB can provide a solution to the problem of disposing of the steadily increasing amounts of unwanted hospital waste and, in addition, increase the usage of the abundant supplies of the nation's coal reserves. During Phase 1 of the contract between DOE, PEDA and DONLEE, the development and the initial testing of a shredding system were accomplished. Phase 2 of the contract includes the installation of the Phase 1 shredding system in a full-scale facility and the utilization of this shredding system at that facility.

The shredding and combustion system was tested co-firing hospital waste and coal from midDecember 1991 through early March of 1992 at DONLEE's 10 million Btu/hr circulating fluidized bed pilot plant. Noninfectious medical waste was provided by the Lebanon VA for the testing. The objectives of this test series were:

- Test the waste shredding/feeding system to demonstrate performance and reliability.

- Determine emissions for coal firing and for coal and waste co-firing.

- Predict the emissions from the Lebanon VA Medical Center proof-of-concept unit from the pilot plant emission tests.

Bituminous coal was fired during the period from mid-December 1991 through the end of January 1992. Shortly after this time, the Pennsylvania Department of Environmental Resources (PA DER) Air Quality requested that the Lebanon VA Medical Center facility should make a decision on the type of fuel to be burned. The fuels under consideration were either bituminous coal or anthracite. Sufficient bituminous testing had already been performed, so an anthracite coal test 
series was run in early March 1992 to gather data in order to make this coal selection and also to determine the sulfur capture as a function of calcium-to-sulfur molar ratio for the anthracite coal.

Several outside laboratories and companies were employed in the sampling and for the analyses during the stack emissions tests. Stack sampling was performed by Energy Systems Associates, Inc. for the stack emission levels of $\mathrm{HCl}$, dioxins/furans, trace metals, particulates and polyaromatic hydrocarbons (PAH). The baghouse composite ash sample for this test series was analyzed for dioxins/furans by Analytical Laboratories. The coal, limestone and ash were analyzed by Warner Laboratory of the Gould Energy Division of Standard Laboratories, Inc. 


\section{PURPOSE}

The purposes or objectives of this test series was

- to determine the emissions rates from the coal firing testing and from the coal and waste co-firing testing at the DONLEE pilot facility;

- to predict the corresponding emissions rates for the Lebanon VA facility using these emissions rates; and

- to determine the performance and reliability of the shredding/feeding system. 


\section{EQUIPMENT DESCRIPTION}

The main component of the combustion system is the fluidized bed combustor. Note that the pilot facility and the unit at the Lebanon VA are identical in their conceptual design. The pilot facility combustor is forty percent of the size of the Lebanon facility. The design velocities are identical. The design condition residence time for the Lebanon VA facility is 3 seconds. The design residence time for the pilot facility is 1.8 seconds. A schematic of the combustor is shown below in Figure 1 .

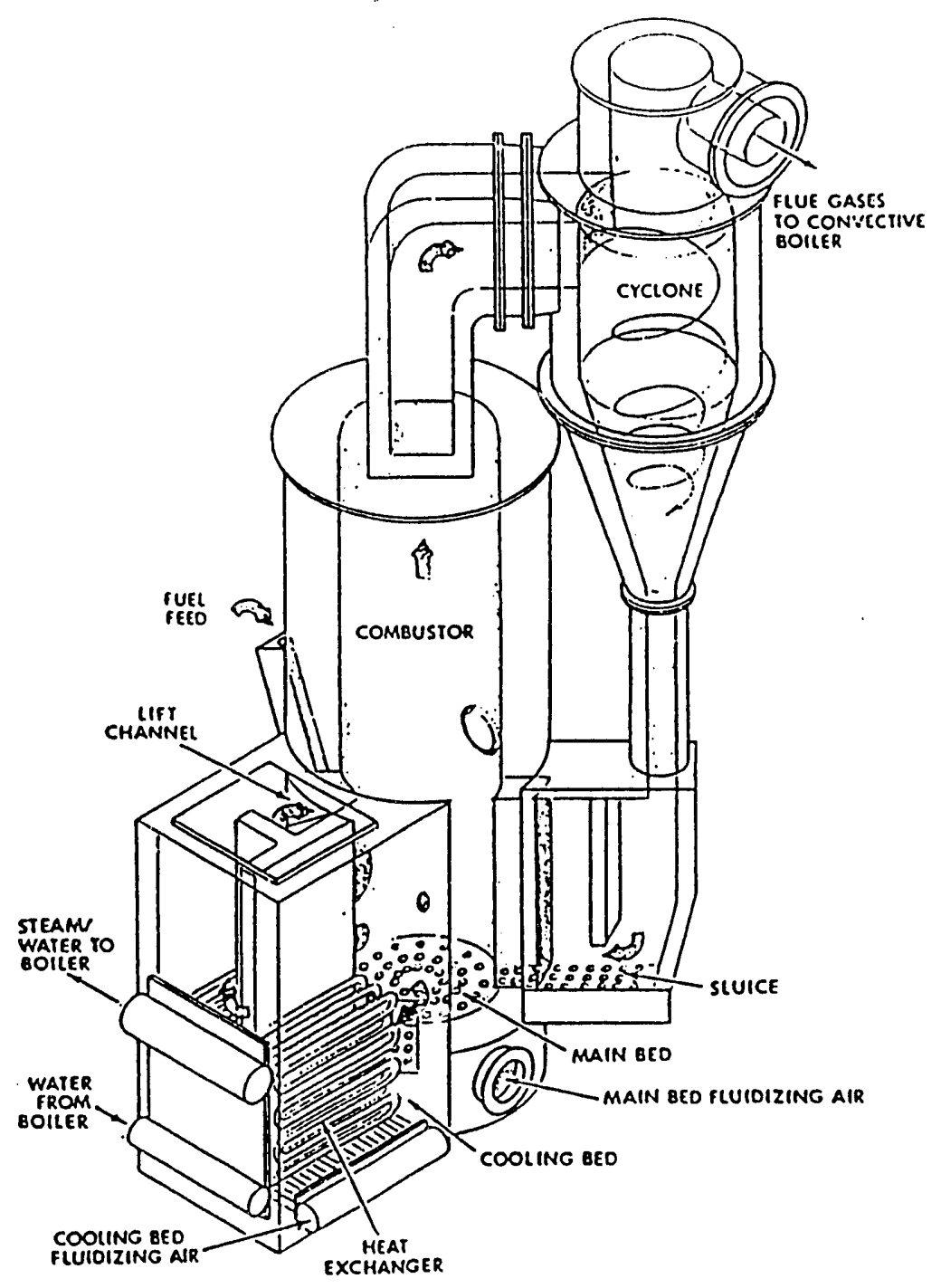

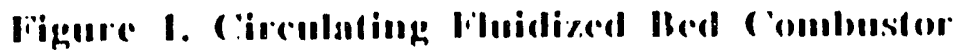


The coal, limestone and waste are fed through fuel feed chutes into the main bed portion of the combustor. The main bed consists of a fluidized bed of solids, where the fluidization velocity entrains the smaller solids into the gas stream and flows through the upper combustor. The gas and solids mixture then enters the cyclone which separates the solids from the gas stream. The solids flow downward into the sluice and back into the combustor. The gases exit the top of the cyclone and flow through the boiler, the economizer, the baghouse and finally exit from the stack.

Temperature control is achieved by using the cooling bed. Solids are drawn from the combustor into the cooling bed, flow over water cooled tubes, and are then returned to the combustor. The solids flow rate, controlled by the gas velocity in the lift channel, determines the combustor temperature. This dynaric control mechanism allows for stable combustor temperatures through the load range, independent of waste feed composition or rate.

The waste is shredded before it enters the combustor. The shredder reduces the waste particle size to 1 " by 3" (approximate). A schematic of the shredding system is shown belc'w in Figure 2.
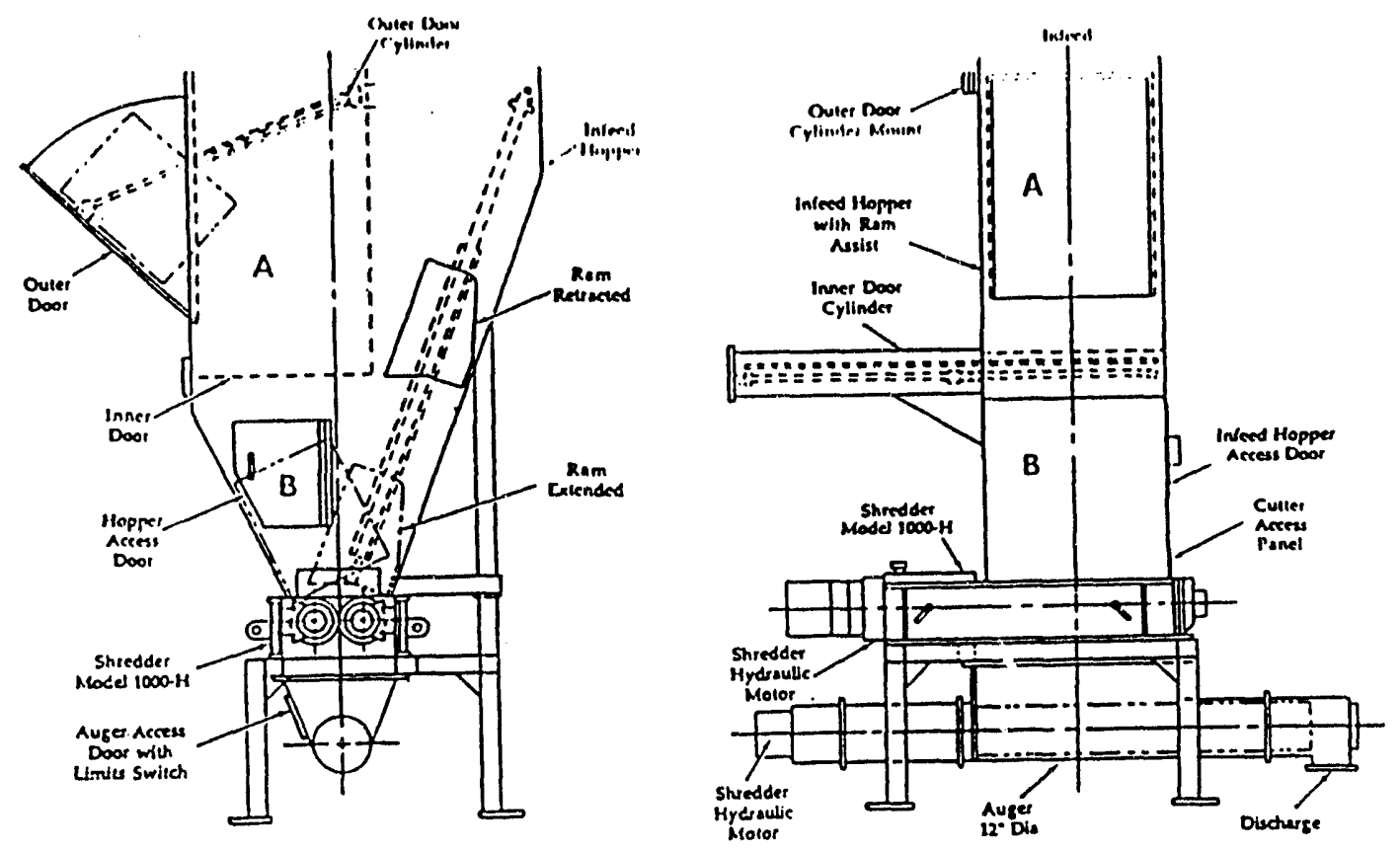

Figure 2. Waste Feed System 
The shredder system that was used during the pilot facility testing will be utilized in the proof-ofconcept system at the Lebanon VA facility.

By shredding the waste to smaller particle sizes, the surface area of the waste is greatly increased. Increasing the waste surface area also increases the heat transfer from the fluid bed combustor to the waste. In turn, the waste heats up faster and is then combusted more efficiently.

The waste is introduced into the shredding system through the outer door. The material then resides in section A of the shredding system. After the outer door is closed behind the waste, the inner door then is opened which allows the waste to fall onto the shredder located in Section B. The inner door then is shut. It must be noted that while the waste is being shredded there are two doors (outer and inner) separating the waste from the immediate environment. A ram is also provided in Section B to insure all material is driven onto the shredder.

The shredder is a rotary shear type where the cutters are 12.5 inches in diameter and rotate at less than 30 RPM. The shredder is driven by two hydraulic pumps with an ability to provide over two thousand $\mathrm{ft}-\mathrm{lbs}$ of torque to the cutter shafts.

The waste falls from the shredder onto the auger which drives the material to the waste feed chute where it falls into the combustor. The waste feed chute is air swept to insure the waste will travel into the combustor bed. Between the auger and the chute is a knife gate valve which can be closed if the combustion conditions are not optimal for waste destruction. 


\section{RELIABILITY TEST DESCRIPTION}

The reliability tests were performed from mid-December 1991 through mid-February 1992. During that time period, the shredder/feed system was operated in conjunction with the circulating fluidized bed combustor system in the DONLEE pilot plant. These tests were conducted to demonstrate the performance and reliability of the shredder/feed system, including demonstrating controllable feed rates for various operating conditions. The shredder system parameters were investigated to determine settings for various feed rates, including $300 \mathrm{lbs}$ per hour, the Lebanon VA facility design feed rate.

\section{A. COAL AND LIMESTONE FEEDSTOCKS}

The bituminous coal used in this test series was Bradford \#44. Its overall size range was 3/8" $\times 0$, with a small amount larger than $3 / 8$ ". This coal typically has a $3.7 \%$ sulfur content and comes from Clearfield County, Pennsylvania. The limestone used during this test series was Compass Quarry limestone being slightly less than $1 / 8$ " $x 0$ in size. This dolomitic limestone comes from Lancaster County, Pennsylvania. The sizes and compositions of these materials are given below in Tables $1 \mathrm{a}$ and $\mathrm{b}$ and $2 \mathrm{a}$ and $\mathrm{b}$. Information on the anthracite (Centralia No. 5 buckwheat) which was used for later tests, as described in sections viii and $i x$, is also given in Tables $1 a$ and $b$ and $2 a$ and $b$.

Table 1a. Coal Size Distributions

\begin{tabular}{|c|c|c|c|}
\hline \multirow{2}{*}{$\begin{array}{c}\text { U.S. MESH } \\
\text { Size }\end{array}$} & \multicolumn{3}{|c|}{ COAL TYPE } \\
\hline & Microns & Bradford $\# 44$ & Centralia No. 5 Buckwheat \\
\hline & & \multicolumn{2}{|c|}{ [Cumulative Plus Percent (\%)] } \\
\hline 3.5 & 5660 & 17.5 & ---- \\
\hline 5 & 4000 & 27.9 & ---- \\
\hline 10 & 2000 & 50.2 & 0.81 \\
\hline 20 & 840 & 72.7 & ----. \\
\hline 30 & 590 & 79.5 & ----- \\
\hline 40 & 420 & $-\cdots--$ & 88.4 \\
\hline 80 & 177 & ---- & 98.6 \\
\hline 100 & 149 & 95.3 & 98.9 \\
\hline 200 & 74 & 98.0 & 99.5 \\
\hline \multirow{2}{*}{\multicolumn{2}{|c|}{$\begin{array}{l}\text { Fifty Percent }(50 \%) \text { Point } \\
\text { Average Rosin - } \\
\text { Rammler dia., } \mu \mathrm{m}\end{array}$}} & & \\
\hline & & 1700 & 880 \\
\hline
\end{tabular}


Table 1b. Limestone Size Distribution

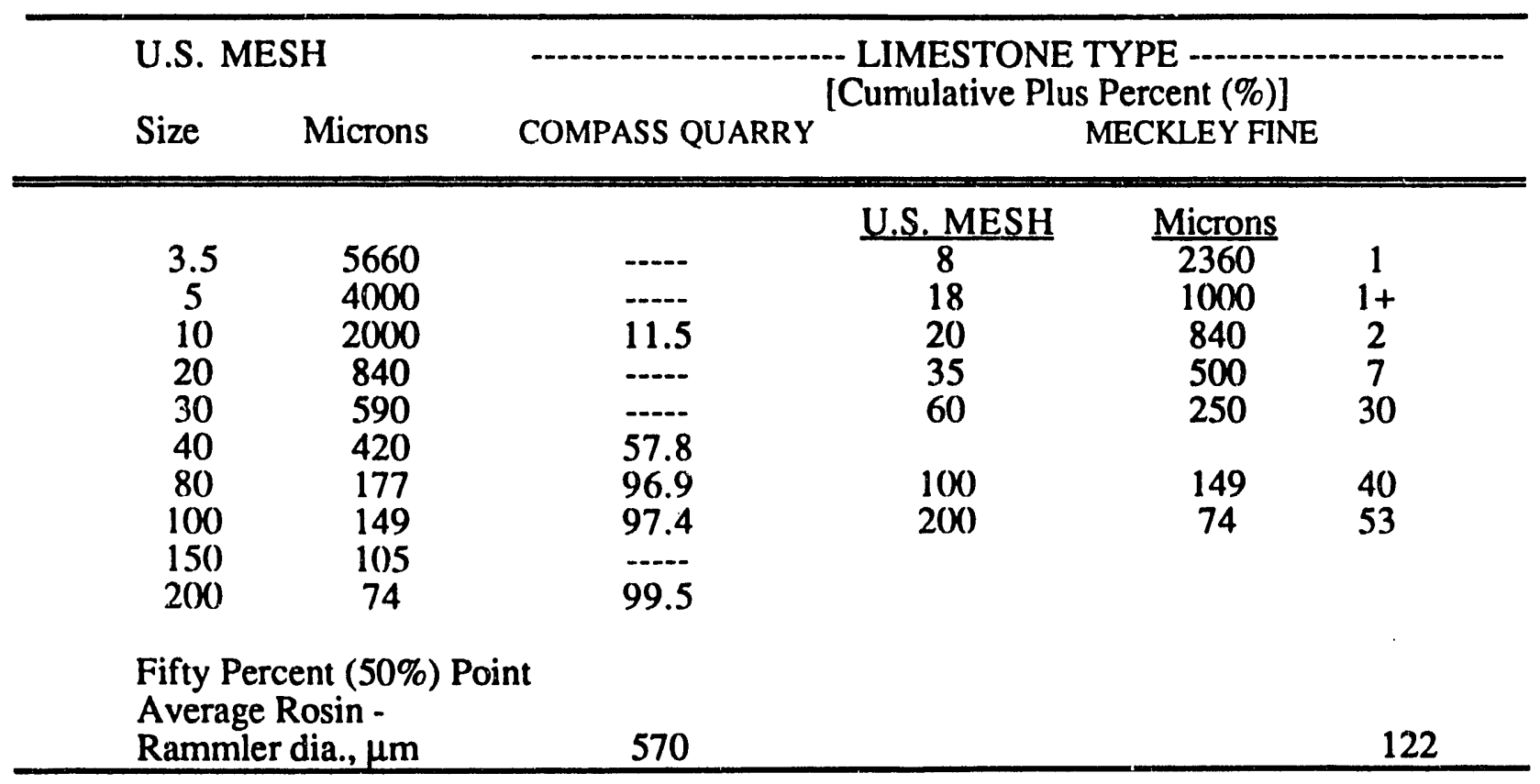

Table 2a. Coal Chemical Compositions

(As Received by Laboratory)

\section{COAL TYPE \\ Bradford \#44 Centralia No. 5 Buckwheat \\ (Composite Sample) (Grab Sample)}

\begin{tabular}{lrr}
\hline $\begin{array}{l}\text { Proximate Analysis, \% } \\
\text { Moisture }\end{array}$ & \\
Fixed Carbon & 5.99 & 12.45 \\
Volatile Matter & $\cdots-.-$ & 71.95 \\
Ash & 12.86 & 3.59 \\
Total & & 12.01 \\
Ultimate Analysis, \% & 100.00 \\
Carbon & & \\
Hydrogen & 68.70 & 70.31 \\
Oxygen & 4.23 & 1.77 \\
Nitrogen & 3.26 & 2.10 \\
Sulfur & 1.12 & 0.69 \\
Ash & 3.71 & 0.63 \\
Moisture & 12.86 & 12.01 \\
Chlorine & 5.99 & 12.45 \\
Total & 0.13 & 0.04 \\
Higher Heating Value & 100.00 & 100.00 \\
\hline
\end{tabular}


Table 2b. Limestone Compositions

(Percent, as fed)

\section{LIMESTONE TYPE}

Compass Quarry Meckley Fine

(Composite Sample)

(Grab Sample)

\begin{tabular}{lrr}
\hline $\mathrm{CaCO}_{3}$ & 43.62 & 81.92 \\
$\mathrm{MgCO}_{3}$ & 34.24 & 3.12 \\
Moisture & 0.95 & 0.02 \\
Chlorine (ppm) & 257.9 & 255.3 \\
Inerts & 21.16 & 14.91 \\
Total & 100.00 & 100.00 \\
$* \quad$ The inerts in the Meckley Limestone typically includes $10-12 \% \mathrm{SiO}_{2}$. \\
\hline
\end{tabular}

Table 3 gives the trace or heavy metal (and fluorine) analyses for the Bradford \#44 (Bituminous)

Coal, the Compass Quarry Limestone, and the Meckley Fine (20 Mesh x 0) Limestone.

Table 3. Trace or Heavy Metal (and Fluorine) Analyses (ppm or $\mathrm{mg} / \mathrm{kg}$ )

\begin{tabular}{lccc}
\hline Element & $\begin{array}{c}\text { Bradford \#44 } \\
\text { COAL }\end{array}$ & $\begin{array}{c}\text { Compass Quarry } \\
\text { LIMESTONE }\end{array}$ & $\begin{array}{c}\text { Meckley Fine } \\
\text { LIMESTONE }\end{array}$ \\
\hline Arsenic & 3.25 & 1.42 & 11.3 \\
Barium & 68.0 & $<75$ & $<0.20$ \\
Beryllium & 1.06 & $<7.5$ & $<() 4$. \\
Cadmium & $<0.10$ & $<7.5$ & $<0.10$ \\
Chromium & 17.0 & 4.5 & $<0.10$ \\
Lead & 4.96 & $<1.25$ & $<0.10$ \\
Mercury & 0.34 & $<0.10$ & $<.50 \mathrm{ppb}$ \\
Nickel & 14.2 & 6 & 32.4 \\
Selenium & 0.95 & $<0.50$ & 6.81 \\
Silver & $<0.10$ & $<0.375$ & $<0.10$ \\
Zinc & 25.7 & 38.9 & 24.9 \\
Fluorine & 78.1 & 9.13 & 106.1 \\
\hline
\end{tabular}




\section{RELIABILITY TEST RESULTS}

The design condition flow rate for the hospital waste at the Lebanon VA is $300 \mathrm{lb} / \mathrm{hr}$. During this test series the shredding feed rate was varied from $50 \mathrm{lb} / \mathrm{hr}$ to roughly $3000 \mathrm{lb} / \mathrm{hr}$. The combustion system proved to be reliable during the over 125 hours of operation, including 44 hours during which waste was shredded and fed into the combustion system. Most tests had average feed rates of approximately $100 \mathrm{lb} / \mathrm{hr}$ but during many tests the feed rate was varied above $300 \mathrm{lb} / \mathrm{hr}$ to determine reliability.

During the earlier testing, waste feed did affect the pressure control on the unit. Opening the outer door allows air inleakage to the unit and the addition mass of waste into the main bed causes the ID fan to modulate. The pressure at the waste feed point is normally controlled to -2 inches water gage. The ID fan control loop was tuned to become more responsive; thus, pressure swings were dampened and reduced to acceptable levels. The new controi loop parameters also retained control well when there was no waste feed.

One blockage occurred just before the January 28 - 29 test series. The waste filled the B Section as seen in Figure 2 in the Equipment Description Section. This blockage was due to grossly overfeeding the waste material. No other blockage occurred during the testing. 


\section{SHREDDER TEST DESCRIPTION}

A two-day test series was run on January 28th and 29th of 1992 . The first day was a baseline test on which only coal and limestone were fed. Medical waste was fed along with the coal and limestone on the second day. Noninfectious medical waste was provided by the Lebanon VA Medical Center. The waste included intravenous (IV) bags, plastic hoses, glass, metal, etc. The heat input during the testing ranged from 40 to 60 percent of design ( 10 million Btu/hr) to keep the residence times approximately the same as the design residence time at the Lebanon VA facility.

Both days of tering included a full range of stack emission tests. The emission tests included :

2 - $\mathrm{HCl}$ tests,

2 - Dioxin/Furan and polyaromatic hydrocarbons (PAH) tests,

2 - Trace metals and particulates tests, and

1 - Hexavalent chromium test (only on the second day).

$\mathrm{O}_{2}, \mathrm{NO}_{\mathrm{x}}, \mathrm{SO}_{2}$ and $\mathrm{CO}$ were monitored continuously.

The test conditions for the hospital waste shredder/feeder tests are presented below in Table 4 .

Table 4. Test Conditions for Hospital Waste Shredder/Feeder Test Series

\begin{tabular}{|c|c|c|c|c|c|c|c|}
\hline $\begin{array}{l}\text { TEST DATE } \\
\text { TEST TIME } \\
\text { * TEST TYPE }\end{array}$ & $\begin{array}{c}\cdots-.-\mathrm{J} \\
1204-1304 \\
(\mathrm{HCl})\end{array}$ & $\begin{array}{l}\text { nuary } 29, \\
1523-1813 \\
\text { (Dioxin/Furan } \\
\text { \& PAH) }\end{array}$ & $\begin{array}{c}1992 \\
2012-2132 \\
\text { (Heavy Metals) }\end{array}$ & $\begin{array}{c}1042-1142 \\
(\mathrm{HCl})\end{array}$ & $\begin{array}{c}\text { January } \\
1353-1655 \\
\text { (Dioxin/Furans } \\
\text { \& PAH) }\end{array}$ & $\begin{array}{c}29,1992 \\
1820-1947 \\
\text { (Heavy Metals) }\end{array}$ & 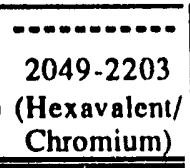 \\
\hline $\begin{array}{c}\text { TOTAL AIR RATE } \\
(\mathrm{lb} / \mathrm{hr})\end{array}$ & 5885 & 5494 & 4740 & 6016 & 5139 & 5129 & 4951 \\
\hline $\begin{array}{ll}\text { TOTAL FLUE GAS } \\
\text { RATE } & (\mathrm{lb} / \mathrm{hr})\end{array}$ & 6358 & 5784 & 5048 & 6406 & 5530 & 5546 & 5340 \\
\hline \begin{tabular}{ll|} 
COAL FEED & \\
RATE & $(\mathrm{lb} / \mathrm{hr})$ \\
\end{tabular} & 366 & 320 & 353 & 380 & 335 & 314 & 279 \\
\hline $\begin{array}{l}\text { HOSPITAL WASTE } \\
\text { FEED RATE } \quad(\mathrm{lb} / \mathrm{hr})\end{array}$ & 0 & 0 & $\underline{0}$ & 58 & 70 & 118 & 126 \\
\hline \begin{tabular}{|l|l|}
\multicolumn{2}{l}{ LIMESTONE FEED } \\
RATE & $(\mathrm{lb} / \mathrm{hr})$ \\
\end{tabular} & 122 & 140 & 120 & 75 & 159 & 158 & 120 \\
\hline $\begin{array}{l}\text { BAGHOUSE ASH } \\
\text { RATE } \\
\text { RAb/hr) }\end{array}$ & - & $=$ & 242.5 & $=$ & - & 241.2 & $=$ \\
\hline $\begin{array}{r}\text { TOTAL HEAT INPUT } \\
\left(\times 10^{-6} \mathrm{Blu} / \mathrm{hr}\right)\end{array}$ & 4.531 & 3.961 & 4.370 & 5.158 & 4.695 & 4.811 & 4.441 \\
\hline $\begin{array}{l}\text { CALCIUM-TO-SULFUR } \\
\text { MOLAR RATIO } \\
\end{array}$ & 1.26 & 1.65 & 1.28 & 0.75 & 1.8 & 1.9 & 1.62 \\
\hline $\begin{array}{r}\mathrm{O}_{2} @ \text { CFB OUTLET } \\
(\mathrm{dry} \%)\end{array}$ & 9.33 & 10.09 & 6.76 & 8.39 & 7.67 & 7.76 & 8.72 \\
\hline $\begin{array}{ll}\text { MAIN BED } & \\
\text { TEMPERATURE } \quad\left({ }^{\circ} \mathrm{F}\right)\end{array}$ & 1585 & 1550 & 1595 & 1623 & 1573 & 1543 & 1544 \\
\hline $\begin{array}{l}\text { COMBUSTOR OUTLET } \\
\text { TEMPERATURE } \\
\text { ( } \mathrm{F})\end{array}$ & 1577 & 1544 & 1600 & 1600 & 1581 & 1552 & 1553 \\
\hline
\end{tabular}

* The "Test Type" refers to the emissions (other than $\mathrm{SO}_{2}, \mathrm{NO}_{x}$ and $\mathrm{CO}$ ) which were measured during a particular test run. All emissions could not be measured simultaneously. 
The coal and limestone used during this two day test series were the same as those used in the reliability tests: Bradford \#44 coal and Compass Quarry limestone. Refer to Tables 1a and b, 2a and $b$ and 3 for the sizes, compositions and heavy metal analyses (along with fluorine analyses) for the materials. 


\section{SHREDDER TEST RESULTS}

\section{A. HCl TESTS}

The stack $\mathrm{HCl}$ emission rate was $0.175 \mathrm{lb} / \mathrm{hr}$ during the baseline $\mathrm{HCl}$ test (coal and limestone feed only). The $\mathrm{HCl}$ stack emission rate was $0.303 \mathrm{lb} / \mathrm{hr}$ during hospital waste and coal co-firing. The higher result is mediated by the fact that the calcium-to-sulfur molar ratio was lower. However, both tests have emission rates significantly less than the BAT requirement of $4 \mathrm{lbs} / \mathrm{hr}$.(1)

Chlorine is captured as calcium chloride by excess calcium oxide (from the limestone) on the baghouse bags. Higher limestone feed rates will result in lower $\mathrm{HCl}$ emission rates. The calcium to sulfur molar ratio during the testing was quite low $(<2)$. The $\mathrm{Ca} / \mathrm{S}$ molar ratio predicted for the Lebanon facility is 3.0. This would probably result in lower Lebanon VA facility $\mathrm{HCl}$ emission rates than the above prediction. Note: A calcium-to-sulfur, chlorine molar ratio would be more correct but since the chlorine in the waste cannot be defined, this molar ratio could not be effectively used.

\section{B . DIOXIN/FURAN AND PAH TESTS}

Dioxins/furans and polyaromatic hydrocarbons (PAH) were sampled once each day of testing. The dioxin/furan emission level was $0.0183 \mathrm{ng} / \mathrm{dscm} @ 7 \% \mathrm{O}_{2}$ total toxic equivalent during coal firing and $0.1089 \mathrm{ng} / \mathrm{dscm} @ 7 \% \mathrm{O}_{2}$ total toxic equivalent during coal and waste co-firing. The total toxic equivalent weighting factors for each individual dioxin and furan were taken from the $\operatorname{EPA}^{(1)}$.

The baghouse ash composite samples were analyzed for dioxins/furans. Each isomer was below the detection limit $(<30 \mathrm{ppb})$. This high detection level results from the interferences that occur in solids analysis.

The EPA priority polyaromatic hydrocarbons (PAH) were measured during the dioxins/furan tests. The pilot plant emission concentration was $1.11 \times 10^{-3} \mathrm{ppm}_{\mathrm{v}} @ 7 \% \mathrm{O}_{2}$ while coal firing and 5.56 x 10-3 ppm $_{\mathrm{v}} @ 7 \% \mathrm{O}_{2}$ while coal and waste co-firing. 


\section{TRACE OR HEAVY METAL AND PARTICULATES TESTS}

Sampling for the particulates and the trace metals arsenic (As), beryllium (Be), cadmium (Cd), chromium $(\mathrm{Cr})$, lead $(\mathrm{Pb})$ mercury $(\mathrm{Hg})$ and nickel $(\mathrm{Ni})$ was conducted on each of the test days. Sampling was taken on the second day for hexavalent chromium $(\mathrm{Cr}+6)$. The metals emission rates for the pilot plant tests are given in Table 5. The metals are compared to industry typical values for waste incinerators with baghouses.(2)(4)(5)

Table 5. Stack Metal and Particulate Emissions with Baghouse

(Emission Rates, lb/hr)

\begin{tabular}{|c|c|c|c|}
\hline & \multicolumn{2}{|c|}{ DONLEE Pilot Plant Tests } & $\begin{array}{c}\text { Typical(2)(4) } \\
\text { Controlled }\end{array}$ \\
\hline $\begin{array}{l}\text { Particulate } \\
\text { Arsenic }\end{array}$ & $2.15 \times 10^{-5}$ & $\begin{array}{c}.57 \\
4.65 \times 10^{-5}\end{array}$ & $6.15 \times 10^{-9}$ \\
\hline Beryllium & $4.56 \times 10^{-6}$ & $9.87 \times 10^{-6}$ & $1.59 \times 10^{-5}$ \\
\hline Cadmium & $1.15 \times 10^{-4}$ & $2.84 \times 10^{-4}$ & $7.95 \times 10^{-7}$ \\
\hline Chromium & $5.37 \times 10^{-4}$ & $1.23 \times 10^{-3}$ & $4.8 \times 10^{-7}$ \\
\hline $\mathrm{Cr}^{+6}$ & & $1.84 \times 10^{-6}$ & \\
\hline Lead & $1.49 \times 10^{-4}$ & $5.04 \times 10^{-4}$ & $1.53 \times 10^{-5}$ \\
\hline Mercury & $2.46 \times 10^{-5}$ & $3.51 \times 10^{-5}$ & $1.53 \times 10^{-3}$ \\
\hline Nickel & $2.42 \times 10.4$ & $5.50 \times 10^{-4}$ & $4.56 \times 10^{-6}$ \\
\hline
\end{tabular}

Material balances were performed for the metals measured in the stack emissions. The output metal rate was derived from the ash analysis as seen in Table 6 along with the stack emission rate seen in Table 5. The capture efficiencies were determined based on the stack emission level.

Table 6. Trace or Heavy Metal (and Fluorine) Analyses

for the Ash from Coal Firing (ppm or $\mathrm{mg} / \mathrm{kg}$ )

\begin{tabular}{lc}
\hline Arsenic & 8.94 \\
Barium & $<0.20$ \\
Beryllium & $<0.03$ \\
Cadmium & $<0.10$ \\
Chromium & 49.80 \\
Lead & 35.60 \\
Mercury & $305.20 \mathrm{ppb}$ \\
Nickel & 40.30 \\
Selenium & 11.10 \\
Silver & $<0.10$ \\
Zinc & 109.10 \\
Fluorine & 79.70 \\
\hline
\end{tabular}


The metal baghouse capture efficiencies are given in Table 7. Closure for each of the material balances of the metals for the coal firing case is shown in this table.

\section{Table 7. Baghouse Capture Efficiencies}

\begin{tabular}{lccc}
\hline METAL & $\begin{array}{c}\text { Closure } \\
(\%)\end{array}$ & $\begin{array}{c}\text { Pilot Facility } \\
\text { Capture Efficiency } \\
(\%)\end{array}$ & $\begin{array}{c}\text { Typical(5) Baghouse } \\
\text { Capture Efficiency } \\
(\%)\end{array}$ \\
\hline Arsenic & 169 & 98.4 & 99.9 \\
Beryllium & 20 & 98.8 & No Data \\
Cadmium & 3 & $87.7^{*}$ & 99.9 \\
Chromium & 189 & 91.8 & 98.7 \\
Lead & 489 & 91.5 & 99.8 \\
Mercury & 170 & 79.5 & No Data \\
Nickel & 173 & 95.8 & No Data \\
Particulate & & $98.2 / 97.9 * *$ & 96.5 \\
\hline
\end{tabular}

Notes:

1. The closure percent is defined as $\frac{\text { OUT }}{\mathrm{IN}} \times 100$,

where: $\quad$ OUT $=$ baghouse ash metal component + stack metal component IN = Coal metal component + limestone metal component + hospital waste metal component (unknown, but " 0 " for baseline test)

2. Capture Efficiency $=\frac{\text { METAL COMPONENT OUT STACK }}{\mathbb{N}} \times 100$

where: $\quad$ IN $=$ Coal metal component + limestone metal component + hospital waste metal component (unknown, but " 0 " for baseline test)

3. The pilot plant baghouse has $\mathbf{1 4} \mathrm{oz}$. Nomex bags that are several years old. Also, the baghouse is undersized for this pilot plant. Thus, the capture efficiencies for this baghouse were rather poor.

* Estimate since only nondetects were found.

** coal firing / coal and waste con-firing

Note: Closure is defined in this table. The input metal flow rate was derived using metal analyses of the Bradford \#44 coal and the Compass Quarry Limestone as shown in Table 3. The output metal rate was derived from the ash analysis as seen in Table 3 along with the stack emission rate seen in Table 6. The capture efficiencies were determined based on the stack emission level.

All of the above (except for cadmium and mercury) metal capture efficiencies in Table 7 were greater than $91 \%$ ). The value for cadmium is the result of nondetect values in the coal, limestone and baghouse ash. Mercury was largely in the vapor state at the stack conditions and thus exhibits lower capture. 
There were no direct measurements for the trace metals in the hospital waste. The hospital waste trace metal concentrations are calculated from the coal and waste co-firing tests using the following procedure:

1) Assume the capture efficiencies are the same as those for the coal firing test.

2) Calculate the total metal input using the capture efficiency and the emission rate.

3) Subtract the metal inputs of the coal and limestone from the total input.

4) Concentrations can then be determined based on $118 \mathrm{lb} / \mathrm{l}$. hospital waste feed rate during the trace or heavy metals test.

The percentage of each metal in the hospital waste was also calculated; the results are shown in Table 8.

Table 8. Trace Metals from Hospital Waste (Estimated or Calculated Values)

\begin{tabular}{lcc}
\hline METAL & ppm or $\mathrm{mg} / \mathrm{kg}$ & $\begin{array}{c}\text { Percentage of Hospital Waste } \\
\text { of Total Metal Input }\end{array}$ \\
\hline Arsenic & 14 & 57 \\
Beryllium & 4.0 & 59 \\
Cadmium & 6.8 & 35 \\
Chromium & 76 & 60 \\
Lead & 37 & 74 \\
Mercury & 0.54 & 38 \\
Nickel & 65 & 59 \\
\hline
\end{tabular}

The metals' concentrations in the hospital waste are higher than the corresponding concentrations in the coal and limestone. The higher feed rates of the coal and limestone tend to mask this fact.

The baghouse can only capture solid particulates or liquid although gases can be "absorbed" by carbon matter in the baghouse and coating the bags. The state (solid, liquid or gas) of a metal is defined by several factors:

- The chemical makeup of the metal and

- the conditions in the process (temperature and pressure).

Halogens (fluorine and chlorine) are present in the coals, the limestones and the hospital wastes. Metal fluorides and metal chlorides can, and most likely do, form along with the metal oxides. The most likely chemical compositions and states that the metals are in as they pass through the stack are: (6), (7) 
- Arsenic chloride

- Beryllium chloride

- Cadmium oxide

- Chromic chloride Chromyl chloride $\left(\mathrm{CrO}_{2} \mathrm{Cl}_{2}, \mathrm{a} \mathrm{Cr}^{+6}\right.$ valence $)$

- Lead chloride

- Mercury (pure)

- Nickel oxide Nickel chloride liquid with some vapor

(M.P. $=3.2^{\circ} \mathrm{F}$, B.P. $=266^{\circ} \mathrm{F}$ )

solid (M.P. $\left.=779^{\circ} \mathrm{F}\right)$

solid (Decomposes at $1652-1832^{\circ} \mathrm{F}$ )

solid (M.P. $=1611^{\circ} \mathrm{F}$ )

liquid with some vapor

(M.P. $=-142^{\circ} \mathrm{F}$, B.P. $\left.=243^{\circ} \mathrm{F}\right)$

solid (M.P. $=934^{\circ} \mathrm{F}$ )

liquid with some vapor

(M.P. $=-38^{\circ} \mathrm{F}$, B.P. $=674^{\circ} \mathrm{F}$ )

solid (M.P. $=3603^{\circ} \mathrm{F}$ )

solid (M.P. $\left.=1886^{\circ} \mathrm{F}\right)$

where:

M.P. = Melting Point at 1 atmosphere pressure

B.P. = Boiling Point at 1 atmosphere pressure

The stack temperature at the pilot plant during the tests was always under $230^{\circ} \mathrm{F}$.

\section{D. $\mathrm{SO}_{2}, \mathrm{NO}_{x}$ and CO EMISSIONS}

The $\mathrm{SO}_{2}, \mathrm{CO}$ and $\mathrm{NO}_{\mathrm{x}}$ emission rates were measured during all seven shrediler tests. Table 9 presents these results.

Table 9. $\mathrm{SO}_{2}, \mathrm{NO}_{x}$ and $\mathrm{CO}$ Emissions

\begin{tabular}{|c|c|c|c|c|c|c|c|}
\hline TEST DATE & \multicolumn{3}{|c|}{....-January 28, $1992 \ldots$} & \multicolumn{4}{|c|}{$\ldots \ldots \ldots$ January 29, $1992 \ldots \ldots$} \\
\hline * TEST TYPE & $\mathrm{HCl}$ & Dioxin/Furan & Mctals & $\mathrm{HCl}$ & Dioxin/Furan & Mctals & $\mathrm{Cr}^{+6}$ \\
\hline $\begin{array}{l}\text { Calcium-10-Sulfur } \\
\text { Molar Ratio }\end{array}$ & 1.26 & 1.65 & 1.28 & 0.75 & 1.8 & 1.9 & 1.62 \\
\hline Sulfur Capture (\%) & 89 & 98 & 98 & 72 & 96 & 95 & 94 \\
\hline $\mathrm{SO}_{2}\left(\mathrm{ppm} @ 7 \% \mathrm{O}_{2}\right)$ & 288 & 62 & 54 & 712 & 105 & 109 & 130 \\
\hline $\mathrm{SO}_{2}\left(\mathrm{lb} / 10^{6} \mathrm{Btu}\right)$ & 0.71 & 0.15 & 0.13 & 1.74 & 0.26 & 0.27 & 0.30 \\
\hline $\mathrm{NO}_{\mathrm{X}}$ (ppm@7\% O2) & 215 & 298 & 56 & 148 & 189 & 178 & 210 \\
\hline $\mathrm{NO}_{\mathrm{X}}\left(\mathrm{lb} / 10^{6} \mathrm{Btu}\right)$ & 0.38 & 0.52 & 0.10 & 0.26 & 0.33 & 0.31 & 0.37 \\
\hline $\mathrm{CO}\left(\mathrm{ppm} @ 7 \% \mathrm{O}_{2}\right)$ & 116 & 111 & $\overline{93}$ & 196 & 180 & 179 & 142 \\
\hline
\end{tabular}

* The "Test Type" refers to the emissions (other than $\mathrm{SO}_{2}, \mathrm{NO}_{x}$ and $\mathrm{CO}$ ) which were measured during a particular test run. All emissions could not be measured simultaneously.

The calcium-to-sulfur molar ratio required to achieve the above $\mathrm{SO}_{2}$ emission rates is plotted below. 


\section{BITUMINOUS COAL AND COMPASS LIMESTONE}

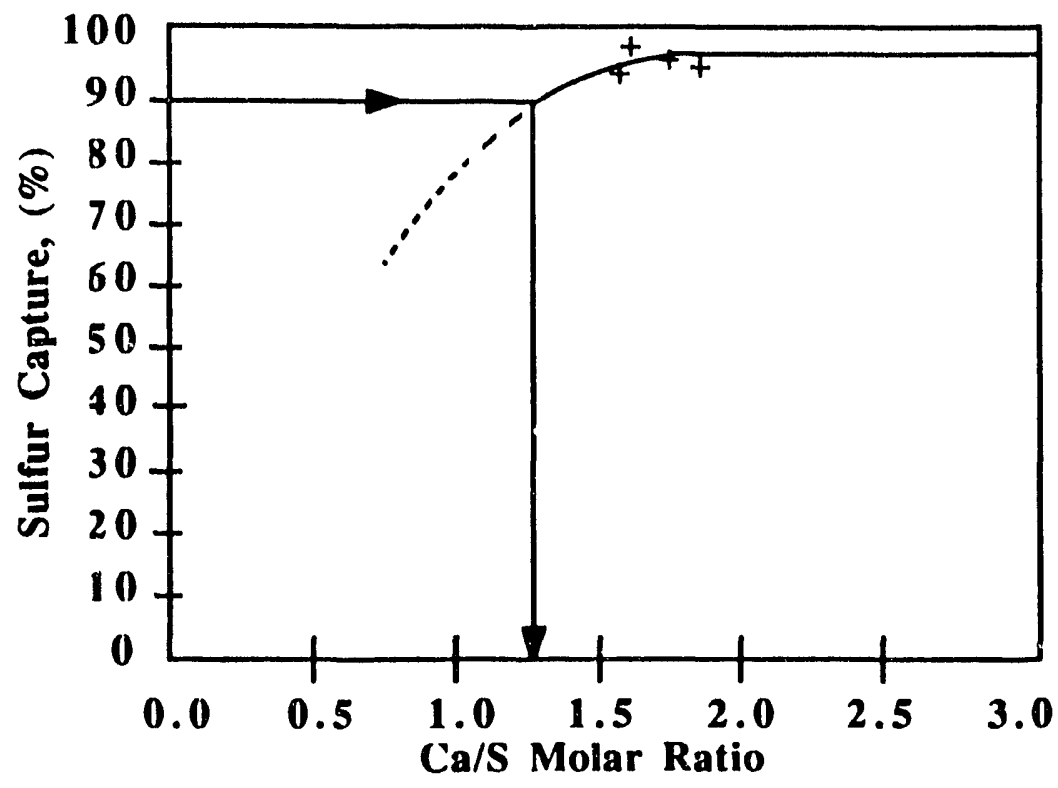

Figure 3. Sulfur Capture during Shredder Tests

Ninety percent sulfur capture was achieved with a calcium-to-sulfur molar ratio of 1.3. The metal test on the 28th and the $\mathrm{HCl}$ test on the 29 th were omitted from the above figure as they were obtained at times when the calcium-to-sulfur molar ratio was decreasing and the results may depict inflated sulfur capture.

The $\mathrm{NO}_{\mathrm{x}}$ emissions are low and are all at or below $0.52 \mathrm{lb} / 10^{6} \mathrm{Btu}$.

The $\mathrm{CO}$ emission values during these bituminous tests are higher than expected. It should be noted that $\mathrm{CO}$ emissions can be increased by the presence of halogen species (chlorine species in this case) in the flue gas ${ }^{(8)}$. The halogen species competes for the radicals needed to convert $\mathrm{CO}$ to $\mathrm{CO}_{2}$; thus increasing the $\mathrm{CO}$ level by not allowing it to convert to $\mathrm{CO}_{2}$. The $\mathrm{CO}$ levels were higher during the coal and waste testing.

The Lebanon facility will be operated firing anthracite coal; emissions of $\mathrm{HCl}$, dioxins/furans and $\mathrm{PAH}$, metals, $\mathrm{SO}_{2}, \mathrm{CO}$ and $\mathrm{NO}_{\mathrm{x}}$ based on the above bituminous coal results cannot be used for prediction purposes. 


\section{ANTHRACITE COAL TEST DESCRIPTION}

Sulfur capture tests were performed using anthracite coal during the March 4-6, 1992 test series. $\mathrm{SO}_{2}, \mathrm{O}_{2}, \mathrm{NO}_{\mathrm{x}}$, and $\mathrm{CO}$ were continuously monitored. These tests determined the limestone to coal feed ratio (calcium-to-sulfur molar ratio) requirement to capture sulfur dioxide. The objective of the test was to define the sulfur capture dependence upon temperature. There were six tests, three calcium-to-sulfur molar ratios were used for two different combustor operating temperatures.

The test conditions for the anthracite test series are given below in Table 10. The coal feed rate in Table 10 was calculated from the $\mathrm{O}_{2}$ concentration at the cyclone outlet.

Table 10. Test Conditions for Anthracite Coal Test Series

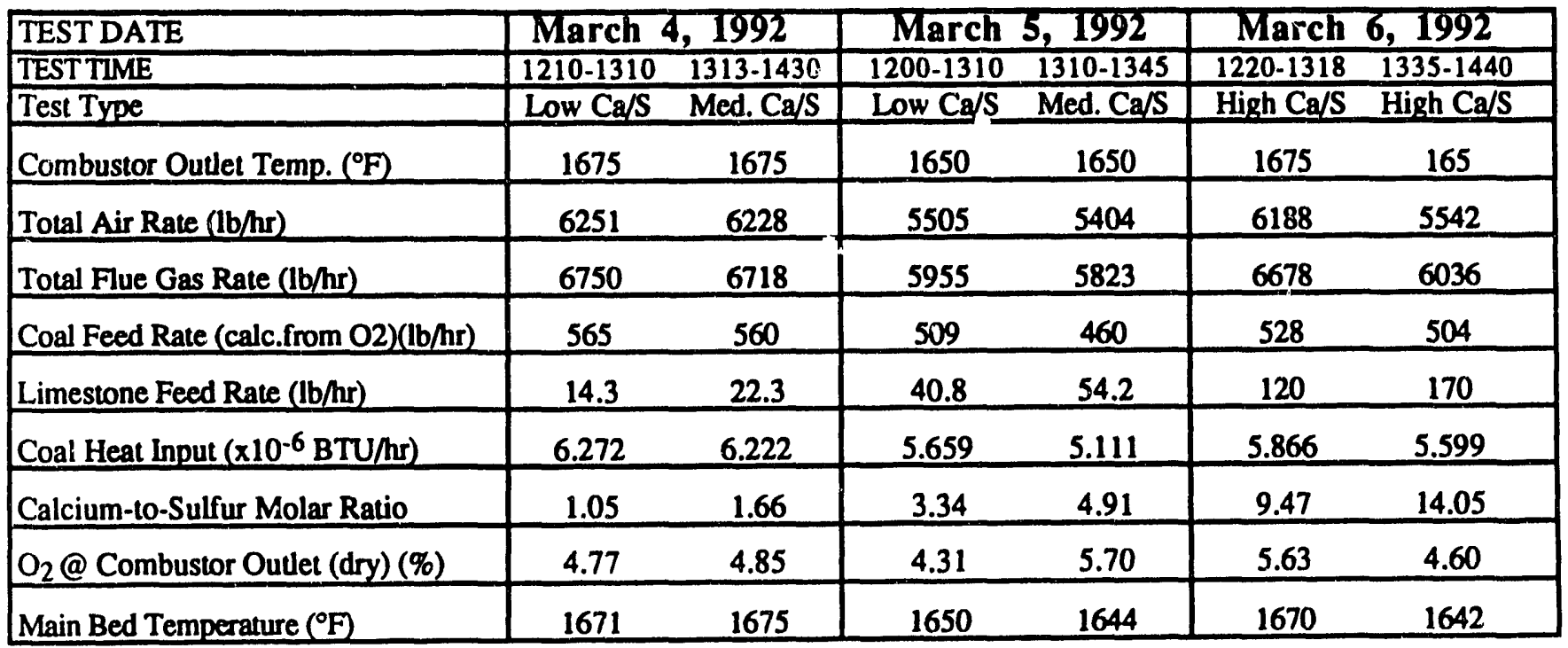

The anthracite coal used in the testing was a coal provided by Centralia Coal Company. The coal was a No. 5 Buckwheat anthracite. The source of this coal is the Tuscarora Mine In East Central Pennsylvania. The limestone used during this test series was Meckley Fine (20 mesh $\times$ 0) limestone. This is a relatively high calcium carbonate limestone $\left(\mathrm{CaCO}_{3}\right.$ is typically 81 to $\left.83 \%\right)$. This limestone is from Herndon, Pennsylvania which is in North Central Pennsylvania.

The sizes and compositions of this coal and limestone are presented in Tables $1 \mathrm{a}$ and $\mathrm{b}$ and $2 \mathrm{a}$ and b. The heavy metals (and fluorine) analyses on the Meckley fine limestone are given in Table 3. 


\section{ANTHRACITE COAL TEST RESULTS}

\section{A. ANTHRACITE SULFUR CAPTURE TESTS}

Data were generated for two combustor operating temperatures: 1650 and $1675^{\circ} \mathrm{F}$. The limestone rate was varied (low, medium and/or high rates) while the coal feed was held roughly constant for both operating temperatures. Table 11 indicates the calcium-to-sulfur molar ratio and corresponding sulfur capture. Table 11 compares this data to the calcium-to-sulfur molar ratio and corresponding sulfur capture based on the measured coal rates. Both sets of data utilized measured limestone rates.

Table 11. Sulfur Capture

\begin{tabular}{|c|c|c|c|c|c|c|}
\hline TEST DATE & \multicolumn{2}{|c|}{ March 4, 1992} & \multicolumn{2}{|c|}{ March 5, 1992} & \multicolumn{2}{|c|}{ March 6, 1992} \\
\hline TESTTIME & $210-1310$ & $1313-1430$ & 1200.1310 & $1310-1345$ & $1220-1318$ & $1335-1440$ \\
\hline Test Type & Low Ca/S & Med. Ca/S & Low $\mathrm{Ca} / \mathrm{S}$ & Med. $\mathrm{Ca} / \mathrm{S}$ & High $\mathrm{Ca} / \mathrm{S}$ & High $\mathrm{Ca} / \mathrm{S}$ \\
\hline Combustor Outlet Temp. $\left.{ }^{\circ} \mathrm{F}\right)$ & 1675 & 1675 & 1650 & 1650 & 1675 & 1650 \\
\hline Coal Rate (Measured) (lb/hr) & 576 & 537 & 503 & 384 & 581 & 626 \\
\hline Coal Rate (Calculated)(lb/hr) & 565 & 560 & 509 & 460 & 528 & 504 \\
\hline Limestone Rate $(\mathrm{lb} / \mathrm{hr})$ & 14.3 & 22.3 & 40.8 & 54.2 & 120 & 170 \\
\hline $\mathrm{Ca} / \mathrm{S}$ Molar Ratio (Measured) & 1.03 & 1.73 & 3.38 & 5.88 & 8.60 & 11.31 \\
\hline $\mathrm{Ca} / \mathrm{S}$ Molar Ratio (Calculated) & 1.05 & 1.66 & 3.34 & 4.91 & 9.47 & 14.05 \\
\hline Sulfur Capture (Mcasured) (\%) & 31.3 & 33.6 & 64.9 & 81.8 & 88.4 & 92.0 \\
\hline Sulfur Capture (Calculated) (\%) & 30.0 & 36.3 & 65.7 & 84.8 & 87.2 & 90.0 \\
\hline $\mathrm{SO}_{2}$ (ppm @ 7\% 02) & 344 & 305 & 163 & 73 & 61 & 48 \\
\hline $\mathrm{SO}_{2}\left(\mathrm{lb} / 10^{6} \mathrm{Btu}\right)$ & 0.84 & 0.75 & 0.40 & 0.18 & 0.15 & 0.12 \\
\hline
\end{tabular}

Agreement between the measured and calculated values of the sulfur capture is good.

These sulfur capture is indicated as a function of calcium-to-sulfur molar ratio in Figure 4. 
ANTHRACITE COAL AND MECKLEY LIMESTONE

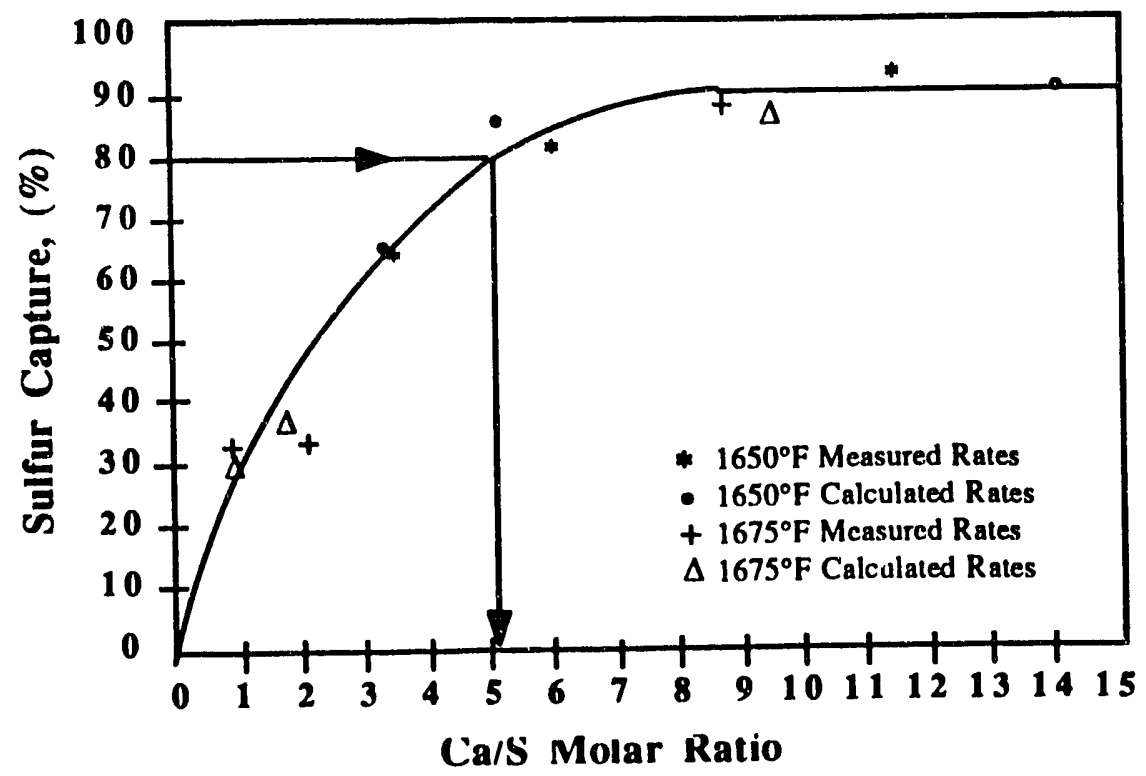

Figure 4. Sulfur Capture during Anthracite Tests

The curve drawn through all of the points shows that the results at the two temperatures, 1650 and $1675^{\circ} \mathrm{F}$ are very similar. The calcium-to-sulfur molar ratio required to achieve $80 \%$ sulfur capture is 5.0. Even thougn the calcium-to-sulfur molar ratios were as low as about 1.0, (Refer to Table 11), the $\mathrm{SO}_{2}$ emissions never exceeded $0.84 \mathrm{lb} / 10^{6} \mathrm{Btu}$.

The coals tested have different sulfur contents: $3.71 \%$ in the Bradford \#44 bituminous coal and $0.63 \%$ in the Centralia anthracite coal. Due to the low sulfur content in the anthracite coal, it is much more difficult to capture the sulfur, and the corresponding calcium-to-sulfur molar ratio required is much higher than that for the bituminous coal for the same sulfur capture. Normally, a calcium-to-sulfur molar ratio of roughly 3.0 or less is sufficient to achieve good sulfur capture (>90 percent) for a bituminous coal. Thus, for the anthracite coal, a calcium-to-sulfur molar ratio higher than 3.0 is required. 


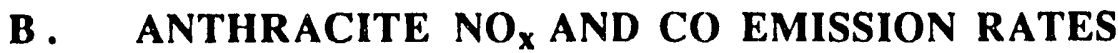

The $\mathrm{NO}_{\mathrm{x}}$ and $\mathrm{CO}$ emissions measured on anthracite coal are presented below.

Table 12. Anthracite Emissions Rates

\begin{tabular}{|c|c|c|c|c|c|c|}
\hline TEST DATE & March & 1992 & March & 1992 & \multirow{2}{*}{\multicolumn{2}{|c|}{$\begin{array}{rr}\text { March } 6,1992 \\
1220-1318 \quad 1335-1440 \\
\end{array}$}} \\
\hline TEST TIME & $1210-131$ & $313-1430$ & $1200-131$ & $310-134$ & & \\
\hline $\mathrm{NO}_{\mathrm{x}}\left(\mathrm{ppm} @ 7 \% \mathrm{O}_{2}\right)$ & 84 & 88 & 67 & 88 & 123 & 103 \\
\hline $\mathrm{NO}_{\mathrm{x}}\left(\mathrm{lb} / 10^{6} \mathrm{Btu}\right)$ & 0.15 & 0.15 & 0.12 & 0.15 & 0.22 & 0.18 \\
\hline $\mathrm{CO}(\mathrm{ppm} @ 7 \%$ O2) & 61 & 67 & 76 & 78 & 69 & 68 \\
\hline
\end{tabular}

The $\mathrm{NO}_{\mathrm{x}}$ emissions are, in general, lower for the anthracite tests than for the tests using bituminous coal. One primary reason for this is that the fuel (coal) bound nitrogen in the anthracite coal is less than two-thirds that of the bituminous coal $(0.69 \%$ versus $1.12 \%$ of nitrogen, respectively). Note that the $\mathrm{NO}_{\mathrm{x}}$ emissions are much lower than $1.0 \mathrm{lb} / 10^{6} \mathrm{Btu}$ required by NSPS(11) for a test facility between $100 \times 10^{6} \mathrm{Btu} / \mathrm{hr}$ and $250 \times 10^{6} \mathrm{Btu} / \mathrm{hr}$.

The CO emissions are all lower than 100 ppm @ 7\% $\mathrm{O}_{2}$ as required by $\mathrm{BAT}^{(2)}$. There are no CO emission regulations in NSPS(11) for our unit size (Lebanon VA or Pilot). No hospital waste was fed during these sulfur capture tests. 


\section{DISCUSSIONS}

\section{A. RELIABILITY TESTS}

The shredder/feeder system has performed reliably and well throughout the reliability, shredder, and anthracite tests. There was one shredder blockage at the end of the reliability tests, just before the January 28-29 tests were about to begin. Waste material filled the B section as seen in Figure 2 in the Equipment Description section. The blockage was due to a gross overfeed of waste material. No blockage has occurred before or since this one-time occurrence. However, the auger exit will be expanded from the current size of 8 "X 12" to $12 " \mathrm{X} \mathrm{12"} \mathrm{to} \mathrm{aid} \mathrm{with} \mathrm{flow.} \mathrm{There} \mathrm{will} \mathrm{also} \mathrm{be} \mathrm{a}$ two-foot high spool section added above the auger so that the storage capacity below the shredder is equal to the loading capacity of one charge volume. The spool piece will allow for slower auger rates with reduced concern for the possibility of material building up to the shredder.

\section{B . SHREDDER TESTS}

Good results with low emission rates were obtained from the $\mathrm{HCl}$, dioxin/furan and PAH, trace metals and particulates, $\mathrm{SO}_{2}$ and $\mathrm{NO}_{\mathrm{x}}$ tests. Only $\mathrm{CO}$ emission rates were not below the BAT guidelines of $100 \mathrm{ppm} @ 7 \% \mathrm{O}_{2}$ dry. The results were obtained from testing using bituminous coal. Refer to the anthracite coal test discussions below.

\section{ANTHRACITE COAL TESTS}

All test emissions $\left(\mathrm{SO}_{2}, \mathrm{NO}_{\mathrm{x}}\right.$ and $\left.\mathrm{CO}\right)$ met Federal regulations and State guidelines.

The selected fuel for the Lebanon VA facility is anthracite coal. The higher temperatures $\left(1650+{ }^{\circ} \mathrm{F}\right.$ versus $1600^{\circ} \mathrm{F}$ ) for anthracite combustion versus bituminous combustion, coupled with higher residence times and better temperature control at the Lebanon VA facility result in lower CO emissions. 


\section{PREDICTIONS}

\section{A. RELIABILITY TESTS}

Initially some concern resulted from the air inleakage through the shredder/feed system into the combustor system. The effects on the system resulting from feeding waste will be lessened at the Lebanon VA facility. Air inleakage will be minimized through the use of sealants and gaskets during installation. The amount of air inleakage will also effect the unit less at Lebanon as the inleakage will be a smaller percentage of the total combustor air. The pilot facility main bed air flow was $2,500-4,000 \mathrm{lb} / \mathrm{hr}$ whereas the Lebanon design main bed air flow will be $14,500 \mathrm{lb} / \mathrm{hr}$. Higher pilot plant air flow rates did show decreased pressure fluctuations and, in general, the air flow changes did not provide large changes in operations.

Modifications to the shredder system should ensure reliable performance of the shredder/feeder system and help avoid blockages of the system. These modifications are:

- The auger exit will be expanded from the current size of 8 " $\times 12^{\prime \prime}$ to $12^{\prime \prime} \times 12^{\prime \prime}$ to increase the flow rate as needed.

- A two-foot high spool piece will be added between the shredder and the auger to give a one charge volume storage capacity below the shredder.

With these improvements and the good performance and reliability of the shredder system seen so far, the future performance of the shredder/feeder system should be very reliable, both in feed rate and control.

\section{B . EMISSIONS}

\section{HCl Tests}

The stack $\mathrm{HCl}$ emission rates for the pilot plant tests were $0.175 \mathrm{lb} / \mathrm{hr}$ for the coal firing case and $0.303 \mathrm{lb} / \mathrm{hr}$ for the coal and waste co-firing case. The predicted Lebanon VA facility emission rates based on the test results are 0.868 during coal firing and $1.354 \mathrm{lb} / \mathrm{hr}$ during coal and hospital waste co-firing. The prediction factor is 4.960 during coal firing and 4.468 during coal and hospital waste co-firing. The prediction factors are simply the ratio of the Lebanon VA heat inputs to the pilot plant heat inputs. The design Lebanon VA firing rate is: 
- Baseline case for coal and limestone only at $30 \%$ excess air

- Coal, limestone and hospital waste at $50 \%$ excess air
$23.53 \times 10^{6} \mathrm{Btu} / \mathrm{hr}$ for $1815 \mathrm{lb} / \mathrm{hr}$ coal

$24.04 \times 10^{6} \mathrm{Btu} / \mathrm{hr}$ for $1673 \mathrm{lb} / \mathrm{hr}$ coal and $300 \mathrm{lb} / \mathrm{hr}$ of hospital waste

where: $\quad$ 1. HHV $=12963 \mathrm{Btu} / \mathrm{lb}$ of coal which was used in the design calculations

2. $\mathrm{HHV}=7830 \mathrm{Btu} / \mathrm{lb}$ of hospital waste, also used in the design calculations

Note: The pilot plant tests both had calcium-to-sulfur molar ratios less than 1.30 where the design calcium-to-sulfur molar ratio for the Lebanon VA facility is 3.0. The predicted results should be correspondingly lower for the Lebanon VA facility.

\section{Dioxin/Furan and PAH Tests}

Predicting the dioxin and furan level at the Lebanon VA based on the test results is difficult as there are competing effects. Dioxins and furans may exist as both vapor and particulate in hospital waste incinerator emissions. As much as $80 \%$ may be in the vapor phase. A portion of the dioxins and furans in the vapor phase can be captured in the baghouse at temperatures below $300^{\circ} \mathrm{F}$ as they condense onto particulate (2). The pilot plant baghouse outlet temperature remained below $230^{\circ} \mathrm{F}$ throughout the entire test series. The baghouse design temperature for the Lebanon VA facility is about $350^{\circ} \mathrm{F}$.

The adverse temperature scaling relationship is in competition with a much more efficient baghouse at the Lebanon VA facility. Refer to Section VI - Item C Trace or Heavy Metals and Particulate Tests. It is believed that the baghouse will be so much more efficient at I.ehanon that it will dominate over the temperature effects. If the competing effects are equal, or not truly pertinent, the emission level will be the same as, if not better than, the pilot facility testing.

Note: The excess carbon can collect dioxin/furans in the baghouse. The results we have obtained so far at the DONLEE pilot facility have always been much lower than the results from other incinerators ${ }^{(2)}$. The flyash in the baghouse contained $7.98 \%$ of organic carbon (composite average) on the first day and $8.56 \%$ on the second day of testing. This available carbon may have contributed to the low dioxin/furan emission rates in these tests $(9)$.

The PAH from the Lebanon VA Facility will be the same as, or slightly higher than, the pilot plant results. PAH are semi-volatile organics. Many of these 20 EPA priority polyaromatic hydrocarbons will remain in the vapor or liquid state at the flue gas temperature of $350^{\circ} \mathrm{F}$ at the Lebanon facility. 


\section{Trace or Heavy Metals and Particulates Tests}

The predicted emission rates for the Lebanon VA facility are presented in Table 13.

\section{Table 13. Stack Metal and Particulates Emissions Predicted Lebanon VA Facility Values $(\mathrm{lb} / \mathrm{hr})$}

\begin{tabular}{|c|c|c|}
\hline \multicolumn{3}{|c|}{$\begin{array}{l}\text { Predicted Lebanon Facility } \\
\text { Baseline }\end{array}$} \\
\hline $\begin{array}{l}\text { Particulate } \\
\text { Arsenic } \\
\text { Beryllium } \\
\text { Cadmium } \\
\text { Chromium } \\
\text { Cr+6 } \\
\text { Lead } \\
\text { Mcrcury } \\
\text { Nickel }\end{array}$ & $\begin{array}{c}0.0076 \\
7.12 \times 10-7 \\
1.51 \times 10-7 \\
3.81 \times 10-6 \\
1.78 \times 10-5 \\
\\
4.94 \times 10-6 \\
8.15 \times 10-7 \\
8.02 \times 10-6\end{array}$ & $\begin{array}{c}0.0150 \\
1.23 \times 10-6 \\
2.61 \times 10-7 \\
7.50 \times 10-6 \\
3.25 \times 10-5 \\
5.26 \times 10-8 \\
1.33 \times 10-5 \\
9.27 \times 10-7 \\
1.45 \times 10-5\end{array}$ \\
\hline
\end{tabular}

The emission rates at the Lebanon VA facility are predicted to be lower due to a superior baghouse. (Refer to Table 5). The emissions predicted at Lebanon VA are only 3.31\% of the pilot plant test emissions based on the coal firing testing. The emission rates are larger in the case of coal and also for waste co-firing (second day's test) than in the case of coal firing for both the pilot plant results and the Lebanon VA facility predicted emission rates.

The prediction factors $\left(\mathrm{PF}_{\mathbf{s}}\right)$ for estimating the metals' and particulates emissions at the Lebanon VA facility are made up of two parts:

$$
\mathrm{PF}_{\text {LEBANON }}=\frac{\text { Lebanon Heat Input }}{\text { Pilot Plant Heat Input }} * \frac{(1-\text { Lebanon Baghouse Capture Efficiency })}{(1-\text { Pilot Facility Baghouse Capture Efficiency })}
$$

The baghouse particulate collection efficiencies were $98.18 \%$ during the coal firing test and 97.88\% during the coal and waste co-firing test. The corresponding particulate emissions during testing was $0.23 \mathrm{lb} / \mathrm{hr}\left(.179 \mathrm{gr} / \mathrm{dscf} @ 7 \% \mathrm{O}_{2}\right)$ during coal firing and $0.57 \mathrm{lb} / \mathrm{hr}$ (.332 gr/dscf @ $7 \% \mathrm{O}_{2}$ ) during coal and waste co-firing. The baghouse particulate efficiency at the Lebanon VA Medical Center facility is predicted to be $99.9888 \%$ based on a report done by Environmental Consultant Company (Appendix). The baghouse will contain P-84 scrimless bags.

The prediction factor during coal firing is 0.0331 and 0.0264 during coal and waste co-firing for all metals but the hexavalent chromium. The hexavalent chromium was sampled during a separate test and therefore has a different prediction factor; the hexavalent chromium prediction factor is 
0.0286. The particulate prediction factors are defined in Section VI Item C Trace or Heavy Metals and Particulate Tests.

The stack temperatures at the Lebanon VA facility will be about $350^{\circ} \mathrm{F}$ which is higher than during the pilot plant tests. The forms of the arsenic, chromium and mercury would be in the liquid or vapor states and should be harder to collect at the Lebanon VA facility. The temperature effect would be in competition with the effect due to higher collection efficiencies in the baghouse at the Lebanon VA facility.

Annual ambient air concentrations for the metals have been estimated using the simple screening procedure as defined by the Environmental Protection Agency(10). The simple procedure does not take into account local environmental conditions; inputs to the model include stack height, stack gas velocity, stack diameter and gas temperature. The simple screening procedure indicates that Lebanon VA will meet the requirements for trace metal emissions. The metals emissions rates will be run on the Screen Model, also defined by $\operatorname{EPA}^{(10)}$, as required by $\operatorname{BAT}^{(1)}$.

\section{4. $\mathrm{SO}_{2}$ Emissions}

The $\mathrm{SO}_{2}$ emissions for the shredder tests were relatively low except for the test in which the calcium-to-sulfur molar ratio was much too low.

\section{NOx Emissions}

The NO, emissions were nll helnw $1.0 \mathrm{lh} / 106 \mathrm{~km}$ which is the NSPS recluirement for $n$ unit sized between $100 \times 10^{6}$ and $250 \times 10^{6} \mathrm{Btu} / \mathrm{hr}$.

\section{CO Emissions}

Very few of the $\mathrm{CO}$ test emissions met the $100 \mathrm{ppm}_{\mathrm{v}}$ at $7 \% \mathrm{O}_{2}$ dry BAT guidelines. However, the fuel at the Lebanon VA facility has been changed to anthracite and those results were much better. All test emissions from the anthracite tests $\left(\mathrm{SO}_{2}, \mathrm{NO}_{\mathbf{x}}\right.$ and $\left.\mathrm{CO}\right)$ met all Federal regulations and State guidelines.

The predictions of $\mathrm{CO}$ emissions for the Lebanon VA facility given below indicate that the BAT guidelines will be met for anthracite coal firing. These low $\mathrm{CO}$ values result from the high operating temperatures, and the longer system residence time and the improved control in the proof-of-concept unit. 
Table 14. Average CO Emission Concentration

$\left(\mathrm{ppm}_{\mathrm{v}}\right)$

\begin{tabular}{ccc}
\hline & Bituminous Coal & $\begin{array}{c}\text { Anthracite Coal } \\
\text { (Lebanon VA Prediction) }\end{array}$ \\
\hline No Waste Fed & 107 & 60 \\
Waste Fed & 174 & $\leq 100$ \\
\hline
\end{tabular}

\section{EMISSION COMPLIANCE}

A summary of the emission levels for the pilot plant shredder tests, firing bituminous coal, and the regulations for emissions are presented in Table 15. The regulations are a mix of NSPS (New Source Performance Standards) and BAT (Best Available Technology). The NSPS requirements are Federal and are typically applied to industrial and utility steam generators. BAT is the Pennsylvania guidelines for incinerators. The unique blend of steam generation and waste combustion proposed by the technology require the use of these hybrid regulations.

The above emissions easily meet the NSPS(11) requirements for $\mathrm{SO}_{2}$ and $\mathrm{NO}_{x}$ in all cases except the $\mathrm{HCl}$ test on January 29, 1992. The calcium-to-sulfur molar ratio was 0.75 for this $\mathrm{HCl}$ test, where as the Lebanon facility will operate at a calcium-to-sulfur molar ratio of 3.0. There is no $\mathrm{NO}_{\mathrm{x}}$ requirement for a combustion system under $100 \times 10^{6} \mathrm{Btu} / \mathrm{hr}$ heat input (Lebanon $\mathrm{VA}$ and Pilot facility are well below this heat input). The requirement indicated in the table is for combustion systems between $100 \times 10^{6}$ to $250 \times 10^{6} \mathrm{Btu} / \mathrm{hr}$ heat input.

The $\mathrm{CO}$ emissions must be less than $100 \mathrm{ppm}$ at $7 \% \mathrm{O}_{2}$ dry to meet Pennsylvania BAT guidelines (2). The emissions during bituminous coal firing do not, in general, achieve this level. It must be noted that the $\mathrm{SO}_{2}, \mathrm{NO}_{\mathrm{x}}$, and $\mathrm{CO}$ emission levels cannot be extrapolated to the Lebanon VA facility as Lebanon will be operated on anthracite coal which has demonstrated much lower $\mathrm{CO}$ levels during the testing.

The total suspended particulate and $\mathrm{HCl}$ are within the BAT guidelines ${ }^{(2)}$ for the Lebanon VA facility. The total suspended particulate emissions for the pilot plant were high during the testing as mentioned in Section VI Item C. The highest dioxin/furan emission level of $0.1089 \mathrm{ng} / \mathrm{dscm} @$ $7 \% \mathrm{O}_{2}$ total toxic equivalent which was predicted is below the $.15 \mathrm{ng} / \mathrm{dscm} @ 7 \% \mathrm{O}_{2}$ total toxic equivalent permit value for the Hershey Medical Center hospital waste incinerator.(3) 
Table 15. Emission Levels Summary Versus Regulations

\begin{tabular}{|c|c|c|c|c|c|}
\hline POLLUTANT & $\begin{array}{c}\text { PILOT PLANT E } \\
\text { w/o Hospital } \\
\text { Wastc }\end{array}$ & $\begin{array}{l}\text { EMISSIONS(a) } \\
\text { w/ Hospital } \\
\text { Waste }\end{array}$ & $\begin{array}{l}\text { LEBANONVA } \\
\text { PREDICTED EI } \\
\text { w/o Hospital } \\
\text { Waste }\end{array}$ & $\begin{array}{l}\text { A FACILITY } \\
\text { MISSIONS (a) } \\
\text { w/ Hospital } \\
\text { Waste }\end{array}$ & REGULATIONS \\
\hline $\mathrm{SO}_{2}\left(\mathrm{lb} / 10^{6} \mathrm{Btu}\right)$ & Bituminous/Anthracilc & c Bituminous & Anthracite & Anthracile & \\
\hline $\begin{array}{l}\text { High } \\
\text { Low } \\
\text { Average }\end{array}$ & $\begin{array}{l}0.71 / \ldots \ldots \\
0.13 / \ldots \ldots \\
0.33 / 0.18\end{array}$ & $\begin{array}{c}1.74(\mathrm{~b}) \\
0.26 \\
0.65\end{array}$ & $\overline{0.18}$ & $\overline{--.}$ & $\begin{array}{c}1.2 \mathrm{lb} / 10^{6} \mathrm{Btu}(\mathrm{c}) \\
\text { (Note: Anthracite } \\
\mathrm{Ca} / \mathrm{S}=5.0 \text { ) }\end{array}$ \\
\hline $\begin{array}{c}\mathrm{NO}_{\mathrm{x}}\left(\mathrm{lb} / 10^{6} \mathrm{Btu}\right) \\
\text { High } \\
\text { Low } \\
\text { Average }\end{array}$ & $\begin{array}{l}0.52 / 0.22 \\
0.10 / 0.11 \\
0.33 / 0.16\end{array}$ & $\begin{array}{l}0.37 \\
0.26 \\
0.32\end{array}$ & $\overline{0.16}$ & $\overline{0.16}$ & $\begin{array}{l}1.0 \mathrm{lb} / 10^{6} \mathrm{Btu}(\mathrm{c}) \\
\left(100 \times 10^{6} \mathrm{Btu} / \mathrm{hr} \leq\right. \\
\text { facility size } \leq \\
\left.250 \times 10^{6} \mathrm{Btu} / \mathrm{hr}\right)\end{array}$ \\
\hline $\begin{array}{c}\mathrm{CO}\left(\mathrm{ppm}_{\mathrm{v}}\right) \\
\text { High } \\
\text { Low } \\
\text { Average }\end{array}$ & $\begin{array}{l}116 / 78 \\
93 / 61 \\
107 / 70\end{array}$ & $\begin{array}{l}196 \\
142 \\
174\end{array}$ & $\overline{60}$ & $\overline{s 100}$ & $\begin{array}{l}100 \mathrm{ppm}_{\mathrm{v}} @ \\
7 \% \mathrm{O}_{2}^{(\mathrm{d})}\end{array}$ \\
\hline $\begin{array}{l}\text { Total Suspended } \\
\text { Particulate } \\
\text { (gr/dscf @ 7\% O2) }\end{array}$ & 0.179 & 0.332 & 0.0059 & 0.0088 & $\begin{array}{l}0.08 \text { gr/dscf @ } \\
7 \% 0^{(e)}\end{array}$ \\
\hline $\mathrm{HCl}(\mathrm{lb} / \mathrm{hr})$ & 0.175 & 0.303 & 0.868 & 1.354 & $\begin{array}{l}4.0 \mathrm{lb} / \mathrm{hr} \text { or } 90 \% \\
\text { capture (e) }\end{array}$ \\
\hline $\begin{array}{l}\text { Dioxins/Furans as } \\
2,3,7,8 \text { TCDD } \\
\text { Total Toxic Equivalent }\end{array}$ & $\begin{array}{c}0.0183 \mathrm{ng} / \mathrm{dcsm} \\
@ 7 \% \mathrm{O}_{2}\end{array}$ & $\begin{array}{c}0.1089 \mathrm{ng} / \mathrm{dscm} \\
@ 7 \% \mathrm{O}_{2}\end{array}$ & $\begin{array}{c}0.0183 \mathrm{ng} / \mathrm{dcsm} \\
@ 7 \% \mathrm{O}_{2}\end{array}$ & $\begin{array}{l}0.1089 \mathrm{ng} / \mathrm{dscm} \\
@ 7 \% \mathrm{O}_{2}\end{array}$ & $\begin{array}{l}0.15 \mathrm{ng} / \mathrm{dscm} \\
@ 7 \% \mathrm{O}_{2}^{(\mathrm{f})}\end{array}$ \\
\hline$\overline{\mathrm{PAH}(\mathrm{g})}$ & $1.11 \times 10^{-3} \mathrm{ppm}$ & $5.5 \times 10^{-3} \mathrm{ppm}$ & $\begin{array}{l}\text { Roughly the sam } \\
\text { plant }\end{array}$ & ne as the pilot & No Regulation \\
\hline $\begin{array}{l}\text { METALS } \\
\text { Arsenic } \\
\text { Beryllium } \\
\text { Cadmium } \\
\text { Hexavalent Chromium } \\
\text { Chromium } \\
\text { Lead } \\
\text { Mercury } \\
\text { Nickel }\end{array}$ & $\begin{array}{c}\mathrm{lb} / \mathrm{hr} \times 10^{-6} \\
21.5 \\
4.56 \\
115 \\
\mathrm{Im} \quad 537 \\
149 \\
24.6 \\
242\end{array}$ & $\begin{array}{c}\mathrm{lb} / \mathrm{hr} \times 10^{-6} \\
46.5 \\
9.87 \\
284 \\
1.84 \\
1230 \\
504 \\
35.1 \\
550 \\
\end{array}$ & $\begin{array}{c}\mu \mathrm{g} / \mathrm{m}^{3} \times 10^{-6(h)} \\
1.34 \\
0.285 \\
7.20 \\
33.6 \\
9.33 \\
1.54 \\
15.1 \\
\end{array}$ & $\begin{array}{c}\mu \mathrm{g} / \mathrm{m}^{3} \times 10^{-6}(\mathrm{~h}) \\
2.32 \\
0.493 \\
14.1 \\
0.0994 \\
61.4 \\
25.1 \\
1.75 \\
27.4 \\
\end{array}$ & $\begin{array}{c}\mu \mathrm{g} / \mathrm{m}^{3} \times 10^{-6}(\mathrm{i}) \\
230 \\
420 \\
560 \\
83 \\
150,000 \\
24,000 \\
3,300 \\
\end{array}$ \\
\hline
\end{tabular}

NOTES:

(a) All tests were conducted using bituminous coal and limestone with the exception of $\mathrm{SO}_{2}, \mathrm{NO}_{x}$ and $\mathrm{CO}$ testing without hospital waste. During the tests where hospital waste was also burned, the heading "with hospital waste" is designated.

(b) During this test the $\mathrm{Ca} / \mathrm{S}$ molar ratio was only 0.75 .

(c) Regulations for $\mathrm{SO}_{2}$ and $\mathrm{NO}_{x}$ are from the New Source Performance Standards (NSPS) (11).

(d) Anthracite coal can achieve this regulation and has been chosen for the Lebanon VA facility.

(e) Incinerator guidelines for Pennsylvania for $<300 \mathrm{lb} / \mathrm{hr}$ feed rate of waste (I).

(f) $0.15 \mathrm{ng} / \mathrm{dscm} @ 7 \% \mathrm{O}_{2}$ corresponds to the concentration of dioxins/furans from the Hershey Medical Center, and results in an ambirmt ronsentration of Iesss than $0.30 \times 10^{-7} \mathrm{Hg} / \mathrm{Nm}^{3}$, as required (I)

(8) Polyaromatic hydrocarbons (PAII) are not specifically regulated.

(h) Ambient Annual Concentration in ug/m $\mathrm{m}^{3}$ from the BAT $(l)$.

(i) These Ambient Annual Concentrations were detcrmined using the simple screening prosedure of the Screen Model. The

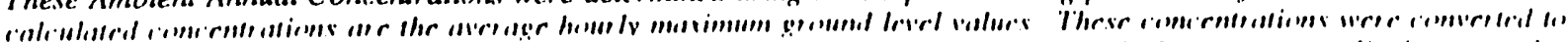

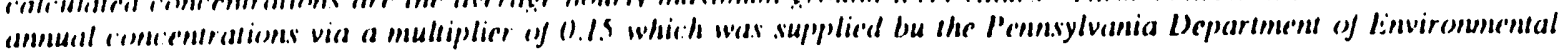
Resources. 
The summary of the anthracite test series emissions and the predicted Lebanon VA facility emissions are also presented in Table 1.5. The $\mathrm{NO}_{\mathrm{x}}$ and $\mathrm{CO}$ data easily meet the regulations(1)(11). The $\mathrm{SO}_{2}$ data meet the PISPS(11) criteria even though the data were taken while determining sulfur capture and were not typical of $\mathrm{SO}_{2}$ operations data.

The $\mathrm{CO}$ emission would increase somewhat when hospital waste is fired with anthracite. The CO emissions would not increase as much as the emissions did during the January 1992 test series, since the combustion temperatures are higher for the anthracite tests $\left(1650+{ }^{\circ} \mathrm{F}\right.$ vs. $\left.1600^{\circ} \mathrm{F}\right)$. The increased residence time at the Lebanon VA facility should also lower the CO emissions. The CO emission rate for the Lebanon facility is predicted to be approximately the same as during the pilot testing for anthracite (see Table 15.) 


\section{CONCLUSIONS}

The shredder/feed system performed reliably and well for over 125 hours operation of the combustion system and for 44 hours of actual shredding at rates that were varied from $50 \mathrm{lb} / \mathrm{hr}$ to approximately $3000 \mathrm{lb} / \mathrm{hr}$. The shredder/feed system will no doubt perform as well or better at the proof-of-concept facility.

The emissions from the bituminous coal tests and coal and waste co-firing met all of the NSPS regulations and BAT guidelines except for $\mathrm{CO}$ emissions (Refer to Table 15). However, anthracite coal which demonstrated much lower $\mathrm{CO}$ emissions was chosen as the selected fuel for the Lebanon VA facility.

The anthracite coal tests demonstrated very good data with respect to $\mathrm{SO}_{2}, \mathrm{NO}_{\mathrm{x}}$ in addition to $\mathrm{CO}$. No other emission data were collected during these tests. Source testing at the Lebanon VA facility will demonstrate these emissions along with the trace metals, $\mathrm{HCl}$, dioxins/furans and $\mathrm{PAH}$ and particulates.

Using anthracite coal, the combustion system proposed for the Lebanon VA facility is predicted to meet all existing pollution emission requirements. 


\section{REFERENCES}

1. Pennsylvania's Department of Environmental Resources Bureau of Air Quality, "Air Quality Permit Criteria Including Best Available Technology for Hospital Infection, Waste Incineration Facilities", Permit Manual, August, 1989.

2. Radian Corporation, "Hospital Waste Combustion Study: Data Gathering Phase", U.S. Environmental Protection Agency, Research Triangle Park, N.C., 1988.

3. Pennsylvania Department of Environmental Resources, Hershey Medical Center Air Quality Permit, 1990.

4. Glasser, H., Chang, D.P.Y., Hickman, D.C., "An Analysis of Biomedical Waste Incineration", Journal of Air Waste Management Association, 41:1180-1188, September 1991.

5. Siebert, P. C., Alston, D. R., Jones, K. H.,"Toxic Trace Pollutants from Incineration", Environmental Progress, Vol. 1, No. 1, February, 1991.

6. Kady, T., Trichon, M., Feldman, J., "Heavy Metals in the Stacks: Where Are They?" Incineration Conference Proceedings in Knoxville, TN, May 13-17, 1991.

7. Dean, J.A., ed., Lange's Handbook of Chemistry, Thirteenth Edition, McGraw Hill, New York, NY, pp 4-12 through 4-133, 1985.

8. Liang, D. T., Anthony, E. J., Loewen, B.K., Yates, D. J., "Halogen Capture by Limestone During Fluidized Bed Combustion", Proceedings of the Eleventh International Conference on Fluidized Bed Combustion, Montreal Canada, April 21-24, 1991.

9. Lanier, W.S. and von Alten, T.R., "Investigations into the Discrepency Between MWI and $M W C$ CDD/CDF Emissions", Incineration Conference Proceedings in Albuqueque, NM, May 11-15, 1992.

10. U.S. Environmental Protection Agency, "Screening Procedures for Estimating the Air Quality Impact of Stationary Sources", August, 1988.

11. U.S. Environmental Protection Agency, "New Source Performance Standards", Federal Register 40 CFR, Part 60 Subpart Dc, July 1, 1991. 


\section{APPENDIX}

\begin{tabular}{|c|}
\hline ENVIRONMENTAL CONSULTANT \\
COMPANY REPORT ON \\
P-84 BAG MATERIAL
\end{tabular}


Ellvirummonial Consultant Company dedicated io filtration science...

P.O. Box 42537 - Phoenix. AZ 85090 - E02.582.5155

Laboratory: 2401 W. Behrerid Dr.. Suito 1 - Fhoerlix. AZ 85027
October 25,1988

I'Lit 6596

Section I

Page 1

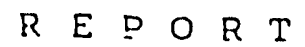

LENZING COMPANY

REFERENCE: V.E.S.A.

It was requested to perform iiltration efficiency studies and resulting resistance pressures to flow on eight filter media candidates.

The selected challenge dist was samples from a standard re-circulating fluidized bed boiler utilizing limestone feed as a part ui the bed composition for gas ue-sulfurization purposes.

The fabric candidates are as follows:

\begin{tabular}{|c|c|c|c|}
\hline [1] & $14 \mathrm{OZ} / \mathrm{SQ}$ & YD & $\begin{array}{l}\text { - IO0\% P-34 - FILAHEIIT WOVEN SCRIM } \\
\text { SINGE (STRONG/MEDIUM) }\end{array}$ \\
\hline$[2]$ & $14 \mathrm{OZ} / \mathrm{SQ}$ & YD & $\begin{array}{l}\text { - 1CO\% P-84 - UNSUPEORTED } \\
\text { SINGE (HEDIUH - NONE) }\end{array}$ \\
\hline$[3]$ & $14 \mathrm{OZ} / \mathrm{SQ}$ & YD & $\begin{array}{l}\text { - } 100 \% \text { P-84 - UNSUPPORTED } \\
\text { SINGE (MEDIUR!/LIGHT) }\end{array}$ \\
\hline$[4]$ & $14 \mathrm{cz} / \mathrm{SQ}$ & YD & $\begin{array}{l}\text { - 100\% } 5-64 \text { - SPUN WOV̈EN SCRIM } \\
\text { SINGE (MEDIUU/LIGHT) }\end{array}$ \\
\hline$[5]$ & $140 Z / S Q$ & YD & $\begin{array}{l}\text { - 100\% ARAHID - SPUN HOVEN SCRIM } \\
\text { SINGE (LIGHT) }\end{array}$ \\
\hline$[6]$ & $14 \mathrm{OZ} / \mathrm{SQ}$ & $Y D$ & $\begin{array}{l}\text { - 100\% .PPS - RASTEX SCRIM } \\
\text { SINGE (LIGHT) }\end{array}$ \\
\hline$[7]$ & $18 \mathrm{OZ} / \mathrm{SQ}$ & $Y D$ & $\begin{array}{l}\text { - ECDE WOVEN FIBERGLASS } \\
\text { TREATMENT - BLUE ILAX }\end{array}$ \\
\hline$[8]$ & $22 \mathrm{OZ} / \mathrm{SQ}$ & $Y D$ & $\begin{array}{l}\text { - ECDE WOVEN FIBEKGLASS } \\
\text { 'TREATMENT - PTFE }\end{array}$ \\
\hline
\end{tabular}

The candidates were subjected to the following. testing criteria common to fluidized ved boiler systems: 


\begin{tabular}{|lll|}
\hline$[A]$ & AIR TO LIOTH RATIO & 4.5 TO 1 \\
\hline$[5]$ & GRALN LOADING PER CUBIC FOOT: & $10( \pm 5 \%)$ \\
\hline$[C]$ & FILTRATION VELOCITY: & $\begin{array}{l}4.5 \text { FEET PER } \\
\text { MINUTE }\end{array}$ \\
\hline [D] & CLEANTNG METHOD: & PULSE JET OFF-LINE \\
\hline
\end{tabular}

Attached are the results of the testing data.

The challenge dust specimen is rated at a fine micron size particle level and represents a high degree of difficulty in textile filter media collection efficiency.

.The median size by actual population is 0.493 misrons with only $14.40 \%$ of the population ccunt above 1 micron size. The conventional particle size reporting method based on voiume;weight gererated a median size of 62.04 microns with $99.45 \%$ of the cust weight above 1 micron size. As explained in the particle size section III, the method utilized for particle sizing is of extreme incortance. Remember, one 50 miczon particles equals one militicn 0.5 micron particle by count however, the weight/volume is the same.

of significance, j.s the lack of larger micron size, particles with only' $\exists$ fractional percentage over 10 micron size ievels.

The presence of fine הicron particles and just as. important, the lack of larger particle size levels necessary for good filter cake fcrmation presents a potential high particle migration factor and high leakage levels for nominal textile filter media.

In general, all P-34 filter media candidates achieved optimum filtration efficiency levels after 6 to 8 hours service

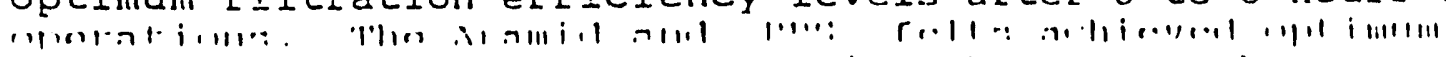
: i itration efficiency Levels during the 8 to 10 hour service operation. The Eiberglass candidates required near 18 hours of service before achieving equilibrium optimum efficiency levels. 
Considering both filtration collection efficiency and resistance to flow capacity the following was generated in order of decreasing performance:

\begin{tabular}{|c|c|c|c|}
\hline [3] & $14 \mathrm{OZ/SQ} Y \mathrm{D}$ & $\begin{array}{l}\text { - } 100 \% \text { P-84 - UNSUPPORTED } \\
\text { SINGE (MEDIUM/LIGHT) }\end{array}$ & (BEST) \\
\hline [1] & $14 \mathrm{OZ} / \mathrm{SQ} Y \mathrm{YD}$ & $\begin{array}{l}\text { - } 100 \% \text { P-84 FILAMENT SCRIM } \\
\text { SINGE (STRONG/MEDIUM) }\end{array}$ & \\
\hline$[4]$ & $14 \mathrm{OZ} / \mathrm{SQ}$ YD & $\begin{array}{l}-100 \% \text { P- } 84 \text { SPUN SCRIM } \\
\text { SINGE (MEDIUI/LIGHT) }\end{array}$ & \\
\hline [2] & $14 \mathrm{OZ} / \mathrm{SQ} Y D$ & $\begin{array}{l}\text { - } 100 \% \text { P- } 84 \text { - UNSUPPORTED } \\
\text { SINGE (MEDIUM/NONE) }\end{array}$ & \\
\hline [5] & $14 \mathrm{OZ/SQ} Y \mathrm{Y}$ & $\begin{array}{l}\text { - } 100 \% \text { ARAMID - SPUN SCRIY } \\
\text { SINGE (LIGHT) }\end{array}$ & \\
\hline$[6]$ & $14 \mathrm{OZ} / \mathrm{SQ} Y \mathrm{Y}$ & $\begin{array}{l}\text { - } 100 \% \text { PDS - RASTEX SCRIM } \\
\text { SINGE (LIGHT) }\end{array}$ & \\
\hline$[7]$ & $18 \mathrm{OZ/SQ} Y D$ & $\begin{array}{l}\text { - ECDE FIBERGLASS } \\
\text { TREATMENT - BLUE NLAX }\end{array}$ & \\
\hline$[8]$ & $22 \mathrm{OZ} / \mathrm{SQ} Y \mathrm{YD}$ & $\begin{array}{l}\text { - ECDE FIBERGLASS } \\
\text { TREATIENT - PTEE }\end{array}$ & (WORST) \\
\hline
\end{tabular}

The felt candidates all generally performed at good collection levels. The fiberglass candidates both the.. 18 ounce and the 22 ounce per square yard media are rated as un-satisfactory efficiency levels. of significance on fiberglass, the majority of particulate leakage occurred directly after pulse cleaning and gradually reduced over a 10 minute period. This strongly indicates that the fiberglass woven filter media requires good filter cake development in order to achieve good collection efficiencies. In the course of pulse cleaning, the cake discharge was sufficient enough to develop this initial high leakage. This situation would appear as a high stack discharge (puffing) after each bag pulse sequence, hence the urisatisfactory performance rating. This high leakage factor was not experienced on any of the needled 
felt candidates. Further, as pressure differentials increased over 4.5 inches water gauge, the high leakage after pulse on the woven fiberglass media correspondingly increased indicative that the woven candidates are also pressure drop sensitive in that over 4.5 inches vater gauge levels, the leakage values substantially increased. Again, the needled felt candidates did not experience this situation.

This evaluation did not generate measurable differences in P-84 products in tarms of the type of scrim on the singe techniques of the candidates as all candidates performed at high collection levels with extremely minimal differences detected.

Based on ash chemistry and field evaluations, a singe Einish is recommended to enhance higher release of any hygroscopic sulphate salt induced agglomerations. 


\section{CHAMBER DATA}

The following attached data reflects the collection efficiency and average resulting pressure differentials of the filte fabric candidates.

The data is reported on a 2 hour cycle with all candidates cleaned and returned to service every 30 minutes. Pressure drop resistances are the average readings for the four full 30 minute cycles of the 2 hour testing duration.

The data equates to a baghouse where bags are just pulsed, ready for pulsing and all intervals in between, hence average resistance values are indicative to baghouse operations.

The woven candidates generated a higher level of variable efficiencies compared to the more consistent efficiencies associated with felt products. This is due to the fact that woven filter fabrics directly after pulse have a variable level of cake discharge, hence the more variable efficiencies.

The performance ranking is based on the composite average cf the last 50 hours of testing and considers both filtration efficiency and operating pressure differentials. 


\section{AVERAGE PERFORMANCE CRITERIA SURTARY}

\begin{tabular}{|c|c|c|c|c|c|c|}
\hline \multicolumn{3}{|c|}{ CANDIDATE } & \multicolumn{3}{|c|}{$\because$ EFFICIENCY } & \multirow{2}{*}{$\frac{\triangle P}{2.93}$} \\
\hline 14 & OZ/SQ & YD & $\mathrm{P}-84$ & - UNSUPPORTED (NEDIUM/LGHT) & 99.9888 & \\
\hline 14 & $\mathrm{OZ} / \mathrm{SQ}$ & $Y D$ & $\mathrm{P}-84$ & $=$ FILAMENT (STRONG/MEDIUT) & 99.9861 & 2.99 \\
\hline 14 & $\mathrm{OZ} / \mathrm{SQ}$ & YD & $\mathrm{P}-84$ & - SPUN (MEDIUM/LIGHT) & 99.9860 & 2.90 \\
\hline 14 & $\mathrm{OZ} / \mathrm{SQ}$ & $Y D$ & $\mathrm{P}-84$ & - UNSUPPORTED (MEDIUM/NONE) & 99.9835 & 2.94 \\
\hline 14 & $\mathrm{OZ} / \mathrm{SQ}$ & YD & ARAMIL & $D$ - SPUN (LIGHT/NONE) & 99.9205 & 3.76 \\
\hline 17 & $\mathrm{OZ} / \mathrm{SQ}$ & $Y D$ & PDS & - RASTEX (LIGHT/NONE) & 99.5803 & 4.13 \\
\hline 18 & $\mathrm{OZ} / \mathrm{SQ}$ & YD & ECDE - & - BLUE MAX & 98.8748 & 4.81 \\
\hline 22 & $\mathrm{OZ} / \mathrm{SQ}$ & YD & ECDE - & - TEFLON B & 98.5810 & 4.92 \\
\hline
\end{tabular}




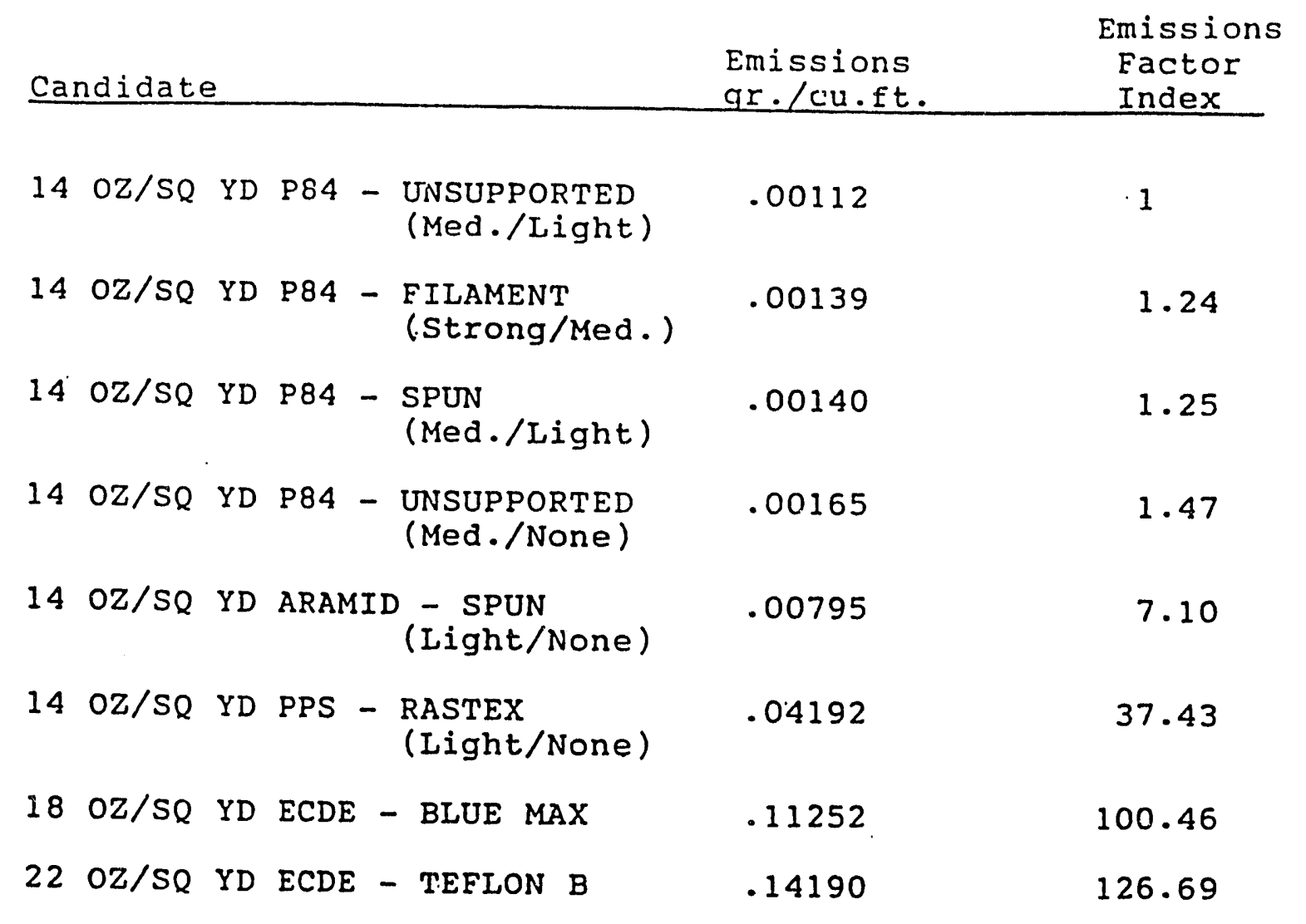



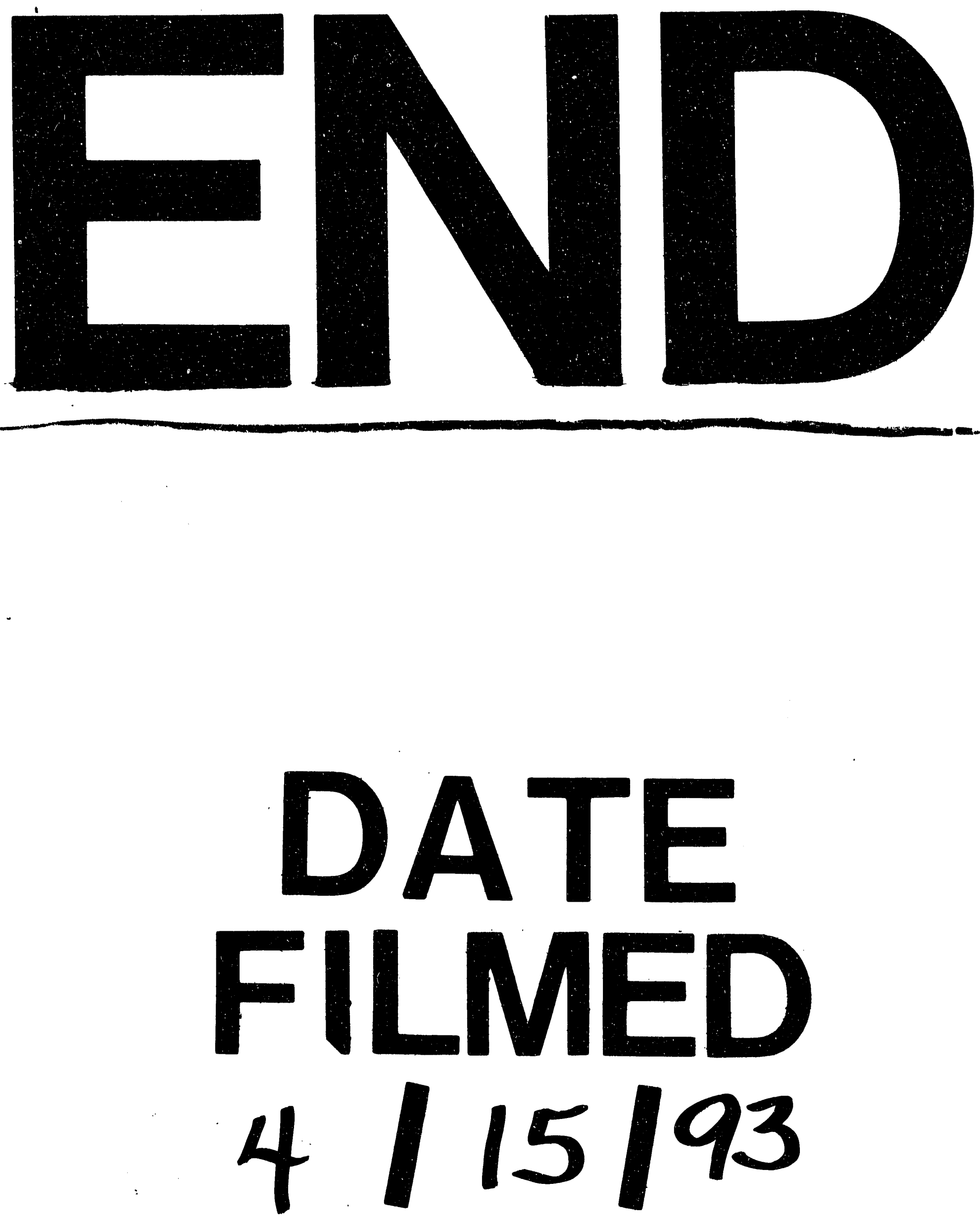

홀 
